\title{
Role Bending: Complex Relationships Between Viruses, Hosts, and Vectors Related to Citrus Leprosis, an Emerging Disease
}

\author{
Avijit Roy, John S. Hartung, William L. Schneider, Jonathan Shao, Guillermo Leon, Michael J. Melzer, \\ Jennifer J. Beard, Gabriel Otero-Colina, Gary R. Bauchan, Ronald Ochoa, and Ronald H. Brlansky
}

First and eleventh authors: University of Florida, IFAS, Plant Pathology Department, Citrus Research and Education Center, 700 Experiment Station Road, Lake Alfred, FL; second and fourth authors: U.S. Department of Agriculture-Agricultural Research Service (USDA-ARS), Molecular Plant Pathology Laboratory, Beltsville, MD; first and third author: USDA-ARS, Foreign Disease-Weed Science Research Unit, Fort Detrick, MD; fifth author: Centro de Investigación La Libertad, CORPOICA, Villavicencio, Colombia; sixth author: Plant and Environmental Protection Sciences, University of Hawaii, 3190 Maile Way, St. John 205, Honolulu 96822; seventh author: Queensland Museum, South Brisbane, Queensland 4101, Australia; eighth author: Colegio de Postgraduados, Campus Montecillo, Texcoco, Edo. De Mex., CP 56230, México; ninth author: Electron and Confocal Microscopy Unit, USDA-ARS, Beltsville, MD; and tenth author: Systematic Entomology Laboratory, USDA-ARS, Beltsville, MD.

Current address of first author: USDA-ARS, Foreign Disease-Weed Science Research Unit, Fort Detrick, MD.

Accepted for publication 10 March 2015.

\begin{abstract}
Roy, A., Hartung, J. S., Schneider, W. L., Shao, J., Leon, G., Melzer, M. J., Beard, J. J., Otero-Colina, G., Bauchan, G. R., Ochoa, R., and Brlansky, R. H. 2015. Role bending: Complex relationships between viruses, hosts, and vectors related to citrus leprosis, an emerging disease. Phytopathology 105:1013-1025.

Citrus leprosis complex is an emerging disease in the Americas, associated with two unrelated taxa of viruses distributed in South, Central, and North America. The cytoplasmic viruses are Citrus leprosis virus $\mathrm{C}$ (CiLV-C), Citrus leprosis virus $\mathrm{C} 2$ (CiLV-C2), and Hibiscus green spot virus 2, and the nuclear viruses are Citrus leprosis virus $\mathrm{N}$ (CiLV-N) and Citrus necrotic spot virus. These viruses cause local lesion infections in all known hosts, with no natural systemic host identified to date. All

CiLV-N infected citrus groves in Mexico were identified as $B$. yothersi and $B$. californicus sensu lato, respectively, and only B. yothersi was detected from CiLV-C2 and CiLV-N mixed infections in the Orinoco regions of Colombia. Phylogenetic analysis of the helicase, RNAdependent RNA polymerase 2 domains and p24 gene amino acid sequences of cytoplasmic leprosis viruses showed a close relationship with recently deposited mosquito-borne negevirus sequences. Here, we present evidence that both cytoplasmic and nuclear viruses seem to replicate in viruliferous Brevipalpus species. The possible replication in the mite vector and the close relationship with mosquito borne negeviruses are consistent with the concept that members of the genus Cilevirus and Higrevirus originated in mites and citrus may play the role of mite virus vector.
\end{abstract} leprosis viruses were believed to be transmitted by one species of mite, Brevipalpus phoenicis. However, mites collected from CiLV-C and

Citrus leprosis, one of the most important emerging citrus diseases in South and Central America, causes severe defoliation, girdled limbs, premature fruit drop, death of twigs, and reduction in both fruit quality and yield, as well as tree death within 3 to 5 years. The disease is not present in the United States, although leprosis was first reported in Florida during 1860s (Knorr 1968) and resulted in serious impacts on citrus production. After 1926, the incidence of leprosis in Florida began to decline. Leprosis was present only in isolated areas on the east coast of Florida in the 1950s (Knorr 1968), and surveys since 1968 have not resulted in any findings in Florida (Childers et al. 2003a). The first report of citrus leprosis in Brazil was in 1931, on sweet orange trees growing in Sorocaba, São Paulo (Bitancourt 1934), with subsequent findings in Argentina (Bitancourt 1940). Today cytoplasmic leprosis is present throughout most of Brazil, most prominently in the south and southeastern states including the citrus-producing regions of São Paulo (Bastianel et al. 2010; Muller et al. 2005; Rodrigues et al. 2003; Salva and Massari 1995). In addition, nuclear leprosis was first reported from Brazil (states of São Paulo,

Corresponding author: R. H. Brlansky; E-mail address: rhby@ufl.edu

*The $\boldsymbol{e}$-Xtra logo stands for "electronic extra" and indicates that two supplementary figures and one supplementary table are published online.

http://dx.doi.org/10.1094/PHYTO-12-14-0375-FI

(C) 2015 The American Phytopathological Society
Additional keywords: Dichorhavirus, flat mite, virus replication.
Minas Gerais, and Rio Grande do Sul) followed by Panama, Mexico and most recently Colombia (Bastianel et al. 2010; Rodrigues et al. 2003; Roy et al. 2013b, 2014). Leprosis has been reported in Colombia along the foothills of the Eastern Mountains of the Orinoco region (León et al. 2006a; Roy et al. 2013a, 2014). In 2005, Citrus leprosis virus $\mathrm{C}$ (CiLV-C) was first reported from Tabasco and Chiapas, two states in southern Mexico (Izquierdo-Castillo et al. 2011), and in 2012 Citrus leprosis virus N (CiLV-N) was reported from Querétaro state, in central Mexico (Roy et al. 2013b) (Fig. 1).

The disease symptoms associated with leprosis are caused by two taxonomically distinct classes of viruses, positive-sense RNA viruses from the genera Cilevirus and Higrevirus, and negativesense RNA viruses from the newly proposed genus Dichorhavirus. CiLV-C and CiLV-C2 are members of the genus Cilevirus, Hibiscus green spot virus 2 (HGSV-2) is the type member of the genus Higrevirus, and CiLV-N and Citrus necrotic spot virus (CiNSV) are members of the genus Dichoravirus, a proposed genus in the family Rhabdoviridae (Dietzgen et al. 2014). Leprosis-associated viruses are present in South, Central, and North America and are either transmitted by or associated with Brevipalpus spp., although no confirmation of mite transmission has been recorded for CiLV-N, CiNSV, and HGSV-2 (Cruz-Jaramillo et al. 2014; Melzer et al. 2012, Roy et al. 2015).

Brevipalpus mites (Tetranychoidea: Tenuipalpidae) are present throughout the world (Beard et al. 2014, 2015). These mites are 
polyphagous in nature, making them very difficult to control. Research on Brevipalpus mites was somewhat neglected until their capacity to transmit pathogenic viruses was demonstrated (Childers and Derrick 2003; Kitajima et al. 2003). The genus Brevipalpus, with more than 300 nominal species, is the second largest genus in the family Tenuipalpidae (Beard et al. 2013; Mesa et al. 2009). Three species of Brevipalpus have been implicated in the transmission of several viruses: B. phoenicis sensu lato (s.1.) (Geijskes), B. californicus s.l. Banks, and B. obovatus Donnadieu (Kitajima et al. 2001, 2003; Kitajima and Alberti 2014; Maeda et al. 1998; Rodrigues et al. 2008; Rodrigues and Childers 2013). The identity of the mite species that serve as vectors of citrus leprosis viruses are yet to be determined, as the taxonomic status of these individual species is currently uncertain and voucher specimens are rarely available for study. Mites historically identified as B. californicus, B. obovatus, and B. phoenicis are widespread in South America, including Brazil, where they have been recorded from at least 234 plant species from 72 families (Childers et al. 2003b; Miranda et al. 2007). Frezzi (1940) demonstrated an association between Brevipalpus mites and citrus leprosis in Argentina ("lepra explosiva"), and likewise, Musumecci and Rossetti (1963) made the first association between B. phoenicis s.l. mites and citrus leprosis in Brazil through field observations and transmission of the disease using mites under experimental conditions. Mites associated with citrus leprosis symptoms in Florida, including voucher specimens, were confirmed as $B$. californicus s.l., suggesting this species group to have been the most likely vector of leprosis in Florida. Although most of these mounted specimens were identified as B. californicus s.l., some of specimens also were identified as $B$. yothersi Baker, a former synonym of B. phoenicis s.l. (Beard et al. 2014, 2015).

In 2009, Citrus volkameriana trees growing in Waimanalo (Oahu, Hawaii), displaying local lesion symptoms similar to citrus leprosis were observed. Short, bacilliform virus-like particles similar to those of CiLV-C were present in the cytoplasm of symptomatic, but not asymptomatic leaf tissues. However, molecular characterization revealed that a novel, tripartite ssRNA virus distantly related to CiLV-C was present in symptomatic tissues (Melzer et al. 2012). This virus was also found in Hibiscus arnottianus trees displaying large, green ringspots in senescent leaves. In 2013, another Cilevirus closely related to CiLV-C2 (Tables 1 and 2, described as CiLV-C2H) was discovered in $H$. rosasinensis growing in Honolulu, HI (Melzer et al. 2013). Symptomatic plants displayed green spots and ringspots in senescing leaves, and could not be detected by a CiLV-C2-specific reverse transcriptionpolymerase chain reaction (RT-PCR) assay (Roy et al. 2013a). Symptomatic ornamental hibiscus plants have been subsequently observed at locations on the islands of Oahu, Kauai, Maui, and Hawaii (M. Melzer, unpublished data), suggesting the virus is widespread in Hawaii. The symptoms observed in Hawaii resemble the ringspot symptoms observed in Brazilian-grown hibiscus infected with the cytoplasmic virus designated as Hibiscus green spot virus (HGSV) (Kitajima et al. 2003). It is not known if the cilevirus identified in hibiscus is able to infect and induce symptoms in citrus, nor whether it is vectored by $B$. yothersi, the previously identified vector (B. phoenicis) of CiLV-C2 (Roy et al. 2013a).

Currently there are no known systemic plant hosts for these viruses. Sweet orange $(C . \times$ sinensis $)$, grapefruit $(C . \times$ paradisi $)$, and mandarin $(C$. reticulata) are susceptible to CiLV-C infection, but lemons $(C . \times$ limon) are immune (Bastianel et al. 2010). Swinglea glutinosa, a perennial ornamental, and Commelina benghalensis, a weed plant, were found to be naturally infected with CiLV-C in Meta, Colombia (León et al. 2008) and São Paulo, Brazil (Nunes et al. 2012a), respectively. Experimentally, Chenopodium quinoa, C. amaranticolor, Gomphrena globosa, H. rosa-sinensis, Malvaviscus arboreus, Grevillea robusta, Phaseolus vulgaris, and Solanum

TABLE 1. Percent nucleotide (above diagonal $*$ ) and amino acid (below diagonal *) identities of RNA1 genomes of Citrus leprosis virus C (CiLV-C), CiLV-C2, and hibiscus infecting Cilevirus sp. (CiLV-C2H) associated with leprosis-like symptoms ${ }^{\mathrm{a}}$

\begin{tabular}{|c|c|c|c|c|c|c|c|c|c|c|}
\hline \multirow{3}{*}{$\begin{array}{l}\text { SI } \\
\text { number }\end{array}$} & \multirow[b]{3}{*}{ Viruses } & \multicolumn{6}{|c|}{ RNA1 } & & & \\
\hline & & \multicolumn{3}{|c|}{ ORF1 (p285) } & \multicolumn{3}{|c|}{ ORF2 (p29) } & \multicolumn{3}{|c|}{ Complete genome } \\
\hline & & 1 & 2 & 3 & 1 & 2 & 3 & 1 & 2 & 3 \\
\hline 1 & CiLV-C & $*$ & 59 & 59 & $*$ & 46 & 47 & $*$ & 58 & 58 \\
\hline 2 & CiLV-C2 & 58 & $*$ & 85 & 34 & $*$ & 92 & ND & $*$ & 86 \\
\hline 3 & $\mathrm{CiLV}-\mathrm{C} 2 \mathrm{H}$ & 58 & 94 & $*$ & 34 & 94 & $*$ & ND & ND & $*$ \\
\hline
\end{tabular}

a ND indicates data not determined.

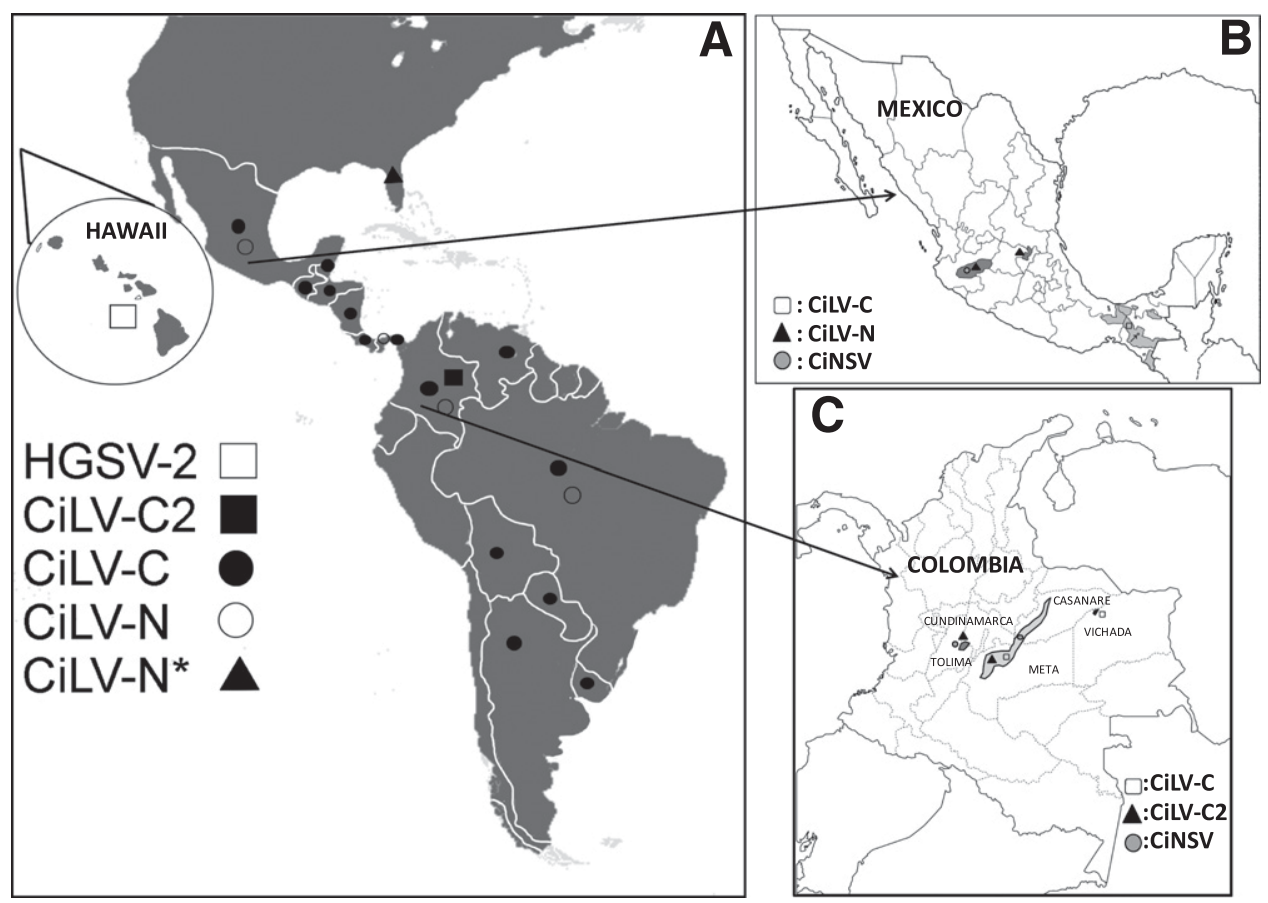

Fig. 1. Geographical distribution of viruses associated with citrus leprosis disease. A, Detailed emergence and distribution of cytoplasmic and nuclear citrus leprosis viruses in B, Mexico and C, Colombia. Asterisk (*) represents the presence of Citrus leprosis virus N (CiLV-N) in Florida prior to 1968. 
violaefolium have been reported as hosts for CiLV-C by different authors (Colariccio et al. 1995; Garita et al. 2013; Groot et al. 2006; Nunes et al. 2012a; Rodrigues et al. 2005). In an expanded experimental host range study of CiLV-C, 140 plant species from 43 families were tested, and 40 species belonging to 18 families produced either localized chlorotic and/or necrotic lesions on leaves identified as positive for CiLV-C (Garita et al. 2014). CiLV-C2 has been recorded from four sweet orange cultivars ('Valencia', 'Delta Valencia', 'Rhode Red Valencia', and 'Cara Cara Navel') (Roy et al. 2013a). $C$. volkameriana and $H$. arnottianus have been reported as hosts of HGSV-2 (Melzer et al. 2012). Field infection of seven citrus species: grapefruit, lemon, lime $(C . \times$ aurantifolia), mandarin, sour orange (C. aurantium), sweet lime (C. limetta), and sweet orange by CiLV-N, and four citrus species: grapefruit, sour orange, sweet orange, and tangerine by CiNSV have been reported in states of Querétaro and Jalisco, Mexico, respectively (Cruz-Jaramillo et al. 2014; Roy et al. 2015).

In this study, novel hosts are reported for CiLV-C2, CiLV-N, and HGSV-2. A careful examination of mites from newly emerging outbreaks identified the vector of CiLV-C as B. yothersi and the vector of CiLV-N as B. californicus s.l. In addition, data that supports the replication of $\mathrm{CiLV}-\mathrm{C},-\mathrm{C} 2$, and $-\mathrm{N}$ in mites and the genetic relationship of cileviruses with insect viruses suggests that the traditional views of plants as hosts and insects as vectors may not apply to viruses associated with citrus leprosis.

\section{MATERIALS AND METHODS}

Sources of leprosis-associated viruses from different countries. Citrus orchards in Meta and Casanare states in Colombia infected with CiLV-C2 or CiLV-N or both viruses were revisited during 2013-14 and leprosis-affected Valencia sweet orange leaves, twigs, and fruits were collected. During the survey leprosis-like symptoms were also observed in S. glutinosa, Dieffenbachia sp., and Hibiscus sp. in Meta state of Colombia. To confirm the presence of leprosis-associated viruses, both symptomatic and nonsymptomatic samples were collected from citrus groves and surrounding areas. To establish the distribution of CiLV-C and CiLV-N in Mexico, a survey was conducted in June 2014. CiLV-C and -N suspect samples and associated Brevipalpus mites from Tabasco and Querétaro states of Mexico, respectively, were collected. Samples were collected from eight different citrus species: grapefruit, lemon, key lime, mandarin, Persian lime, sour orange, sweet lime, and sweet orange. Healthy leaf samples, leprosis-affected leaf samples, and their associated mites were examined to identify the viruses and mites as described below.

In Kula on the island of Maui, Hawaii, a citrus farm growing primarily mandarin, sweet orange, and Persian lime was visually inspected for leaf blotch symptoms reported by the citrus grower. Approximately 60 trees of each variety were inspected. Symptomatic and asymptomatic leaf and fruit tissue were collected from the field and transported in double containment on ice to the laboratory and stored at $4{ }^{\circ} \mathrm{C}$. In addition, a small hau tree (H. tiliaceus) growing adjacent to $H$. arnottianus plants infected with HGSV-2 on the University of Hawaii at Manoa campus displayed green and red leaf blotch symptoms on senescing leaves, which were similar in appearance to the symptoms displayed by $H$. arnottianus infected with HGSV-2. Symptomatic leaves were collected and stored at $4^{\circ} \mathrm{C}$ for RT-PCR detection assay.

RNA extraction and RT-PCR. Approximately $100 \mathrm{mg}$ of leaf tissue (equivalent to 6 to 12 lesions) or fruit peel of healthy and leprosis-affected citrus, S. glutinosa, Dieffenbachia sp., and Hibiscus sp. was frozen in liquid nitrogen and pulverized with a mortar and pestle. Total RNA was then isolated using a Qiagen RNeasy Mini kit (Valencia, CA) following the manufacturer's instructions. Total RNA was eluted in $60 \mu \mathrm{l}$ of nuclease-free water. For some samples total RNA was extracted from single or overlapped lesions using the same approach. RNA titers were quantified by spectrophotometry, and equal amounts of RNA were used as templates for RT-PCR. Primer pairs specific to CiLV-C (Locali et al. 2003), CiLV-C2 (Roy et al. 2013a), CiLV-N (Roy et al. 2015), and HGSV-2 (Melzer et al. 2012) were used to detect these viruses from leprosis-affected tissues collected from Colombia, Hawaii, and Mexico following the published RT-PCR protocol (Roy et al. 2013a). Moreover, primers specific for cileviruses that infect hibiscus (Melzer et al. 2013) also were utilized to detect viruses related to $\mathrm{CiLV}-\mathrm{C} 2$ in these samples. The PCR amplicons were resolved in 1\% agarose gels and stained with GelRed (Biotium, Hayward, CA) and visualized under UV light, and then cloned with the TOPO TA cloning vector (Life Technologies, Carlsbad, CA) following the manufacturer's protocol. The clones were bidirectionally sequenced.

Identification of Brevipalpus spp. using low temperature scanning electron microscopy (LT-SEM). Slide-mounted specimens of Brevipalpus spp. were collected from the Americas and examined at $\times 1,000$ magnification using a DIC and phase contrast Zeiss Axioscope microscope. As both morphological and molecular evidence strongly suggests that the taxa B. phoenicis and B. californicus actually comprise several cryptic species (Beard et al. 2013; 2015; Navia et al. 2013; Rodrigues et al. 2004), our Brevipalpus spp. identifications were made utilizing multiple distinguishing characters (Table 3, Supplementary Figs. 1 and 2), including cuticular microplates as outlined in Beard et al. (2015). Due to the recent taxonomic resolution within these species groups, specimens previously identified as B. phoenicis or B. californicus are referred to here as $B$. phoenicis s.l. and B. californicus s.l. unless vouchers were examined and a current species identification could be made. The true $B$. phoenicis sensu stricto, while recorded on Citrus spp. hosts, has not yet been associated with citrus leprosis (Beard et al. 2015). Specimens in $70 \%$ ethanol from Brazil (5 samples), Colombia (3 samples), and Mexico (21 samples) were also used for LT-SEM studies, utilizing the technique outlined by Bolton et al. (2014). Images were captured using a 4pi Analysis System (Durham, NC). Because the specimens were not tightly secured to the adhesive tabs, it was often possible to remove the specimens from the LT-SEM and turn them over to the view ventral side; thus, both dorsal and ventral images were taken of individual mites.

Mite transmission. Suspected nonviruliferous Brevipalpus mites were collected from a leprosis-free citrus grove and an established leprosis virus-free laboratory mite colony in Colombia following previously described protocols (Nunes et al. 2012b; Roy et al. 2013a).

TABLE 2. Percent nucleotide (above diagonal*) and amino acid (below diagonal*) identities of RNA2 genomes of Citrus leprosis virus C (CiLV-C), CiLV-C2, and hibiscus infecting Cilevirus sp. (CiLV-C2H) associated with leprosis-like symptoms ${ }^{\mathrm{a}}$

\begin{tabular}{|c|c|c|c|c|c|c|c|c|c|c|c|c|c|c|c|c|c|c|c|}
\hline \multirow[b]{3}{*}{ SI number } & \multirow[b]{3}{*}{ Viruses } & \multicolumn{15}{|c|}{ RNA2 } & & & \\
\hline & & \multicolumn{3}{|c|}{ ORF1(p15) } & \multicolumn{3}{|c|}{ ORF2 (p7) } & \multicolumn{3}{|c|}{ ORF3 (p61) } & \multicolumn{3}{|c|}{ ORF4 (p32) } & \multicolumn{3}{|c|}{ ORF5 (p24) } & \multicolumn{3}{|c|}{ Complete genome } \\
\hline & & 1 & 2 & 3 & 1 & 2 & 3 & 1 & 2 & 3 & 1 & 2 & 3 & 1 & 2 & 3 & 1 & 2 & 3 \\
\hline 2 & CiLV-C2 & 15 & * & 79 & ND & $*$ & 88 & 30 & $*$ & 83 & 50 & $*$ & 83 & 60 & $*$ & 88 & ND & $*$ & 78 \\
\hline 3 & CiLV-C2H & 17 & 77 & $*$ & ND & 50 & $*$ & 31 & 85 & * & 49 & 91 & $*$ & 60 & 96 & $*$ & ND & ND & * \\
\hline
\end{tabular}

${ }^{a}$ ND indicates data not determined. 
For transmission studies, 80 to 100 healthy mites were fed on $C$. sinensis and $S$. glutinosa leaves with leprosis lesions. After a $24 \mathrm{~h}$ acquisition access period (AAP), approximately 50 mites were collected, submerged in $90 \%$ ethanol, and later assayed for CiLVs. The remaining mites were placed on virus-free sweet orange and $S$. glutinosa seedlings to continue the transmission experiment in order to confirm Koch's postulates following the protocol described by Roy et al. (2013a). The experiment was repeated twice using four replications. To detect the presence or absence of leprosis viruses in suspected viruliferous and nonviruliferous Brevipalpus sp., approximately 15 to 20 mites from each group were collected and tested by leprosis virus specific RT-PCR as described by Roy et al. (2015).

Detection of leprosis viruses in Brevipalpus sp. vectors by RT-PCR. Nonviruliferous Brevipalpus mites were collected from a citrus leprosis-free orchard and from virus-free mite colonies in La Libertad, Meta, Colombia. Two suspected viruliferous Brevipalpus mite samples were collected from a leprosis-affected orchard in La Libertad and a third mite sample was collected from a leprosis virus transmission study. To detect leprosis viruses inside the mites, after the $24 \mathrm{~h} \mathrm{AAP,} \mathrm{approximately} 40$ to 50 mites were frozen in liquid nitrogen and crushed in 2-ml Eppendorf tubes using a small plastic pestle. Total mite RNA was extracted using the Qiagen RNeasy Fibrous Tissue Mini kit (Valencia, CA) following the manufacturer's instructions, with final elution using 15 to $20 \mu \mathrm{l}$ of elution buffer. RNA yield and quality was measured with a NanoDrop ND-1000 Spectrophotometer (Wilmington, DE) and the RNA was stored at $-20^{\circ} \mathrm{C}$ for subsequent analysis. A mixture of leprosis-associated virus-specific reverse strand primers $(2 \mu \mathrm{M})$ (Locali et al. 2003; Melzer et al. 2012, 2013; Roy et al. 2013a, 2014 b) was added separately to the total RNA of nonviruliferous and viruliferous mites and cDNA synthesis (total volume $25 \mu \mathrm{l}$ ) followed the manufacturer's protocol (Invitrogen, Carlsbad, CA). PCR was performed and amplicons were resolved by gel electrophoresis, purified, cloned, and bidirectionally sequenced using the previously described protocol (Roy et al. 2013a).

Detection of leprosis virus replication within Brevipalpus spp. The modified two-step RT-PCR protocol described above (Kubo et al. 2011, Roy et al. 2013a) also was performed to detect replication intermediates of leprosis viruses (CiLV-C, CiLV-C2, and CiLV-N) in Brevipalpus mites. Negative-strand RNA specific cDNA from CiLV-C and CiLV-C2 was synthesized using a forward primer during cDNA synthesis, and positive-strand specific cDNA from CiLV-N was synthesized with the reverse primer that was utilized for RT-PCR detection assays of leprosis-associated viruses (Supplementary Table 1). cDNA was purified using the Qiagen PCR purification kit and PCR was performed following the previously described protocol (Roy et al. 2013a) with leprosis virus species specific forward and reverse primers. To confirm the presence of CiLV-C, $-\mathrm{C} 2$, and $-\mathrm{N}$ in Brevipalpus mites, the same RNA extracts were used as templates for traditional cDNA synthesis utilizing the reverse primer of the encapsidated strand of each virus.

Phylogenetic analysis. Phylogenies were constructed for the helicase and RNA-dependent RNA polymerase (RdRp), and a hypothetical (p24) protein using deduced amino acid sequences obtained from NCBI GenBank. The helicase and replicase domains of the RdRp2 were extracted using the SMART domain program (http://smart.embl-heidelberg.de). p24 sequences were used to search the NCBI nr database and the resulting blast hits were used in the construction of the phylogenetic tree. In some cases sequences were not annotated as a p24 gene, but relevant sequences based on e-values were included in the trees. Amino acid sequences were aligned using Clustal X software. Phylogenies were constructed with the neighbor-joining and maximum parsimony methods in MEGA 6 (Tamura et al. 2013) with 1,000 bootstrap replications. Branches with bootstrap values greater than 70 were retained.

\section{RESULTS}

Natural infection of rutaceous and nonrutaceous plants by leprosis-related viruses. Surveys were conducted in Colombia, Hawaii, and Mexico to determine the distribution of the cytoplasmic and nuclear citrus leprosis-associated viruses. During the survey in Colombia, leprosis-like symptoms were observed in Dieffenbachia sp. and S. glutinosa. The symptoms observed in $S$. glutinosa were distinct from the symptoms noted in Dieffenbachia sp. The chlorotic lesions with 'nail head' necrotic centers surrounded by broad yellow haloes observed on $S$. glutinosa (Fig. 2A) were similar to the symptoms produced by CiLV-C on S. glutinosa (Leon et al. 2008) and the symptoms of CiLV-C and -C2 observed on different sweet orange cultivars (Roy et al. 2013a). The lesions observed on Dieffenbachia sp. were smaller in size, dark brown in color, and without chlorotic haloes (Fig. 2B). Small light brown lesions also were observed, often coalesced in advanced stages of infection (data not shown). No symptoms were observed on twigs of S. glutinosa or stems of Dieffenbachia. Many green ring lesions with internal chlorotic spots were observed in a senescing H. rosa-sinensis leaf in Meta, Colombia (Fig. 2D). H. rosa-sinensis showed chlorotic spots but not senescence, when Brevipalpus mites infected with CiLV-C were used for experimental inoculation (Nunes et al. 2012b). Persian lime leaves with distinct necrotic lesions with yellow haloes (Fig. 2C) were collected from Querétaro state in Mexico. The necrotic lesions were smaller in size (3 to $5 \mathrm{~mm}$ ) than typical leprosis symptoms produced by cytoplasmic leprosis viruses (6 to $12 \mathrm{~mm}$ ). Coalescence of necrotic lesions was not observed.

TABLE 3. Taxonomic criteria for the classification of three Brevipalpus species associated with citrus leprosis disease complex

\begin{tabular}{|c|c|c|c|}
\hline Taxonomic characters & B. californicus s.1. ${ }^{\mathrm{a}}$ & B. yothersi & B. phoenicis s.1. \\
\hline Number solenidia on tarsus II & 2 & 2 & 2 \\
\hline Dorsal opisthosomal setae $f 2$ & Present & Absent & Absent \\
\hline $\begin{array}{l}\text { Dorsal cuticle pattern between setae } \\
e 1 \text { and } h 1\end{array}$ & $*$ & V-shaped folds & Transverse folds \\
\hline Dorsal cuticle pattern laterad setae $e 1$ & $*$ & Regular reticulate cells & Large rounded cells \\
\hline Cuticle pattern on ventral plate & $*$ & Separate warts & Transverse bands \\
\hline Cuticle pattern on genital plate & $*$ & Large warts/cells & Large warts/cells \\
\hline Spermatheca & * & $\begin{array}{l}\text { Long fine duct ending in oval vesicle with } \\
\text { thick distal stipe }\end{array}$ & Thick duct ending in small distal bulb \\
\hline Seta on palp femurogenu & $*$ & Narrow, tapered, barbed & Broad, flat, barbed \\
\hline Cuticular microplate pattern & $*$ & $\begin{array}{l}\text { Separate rounded plates with series of } \\
\text { parallel ridges dorsally }\end{array}$ & $\begin{array}{l}\text { Separate irregularly shaped plates with } \\
\text { irregular multidirectional ridges dorsally }\end{array}$ \\
\hline
\end{tabular}

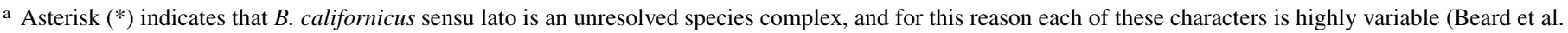
2013). 
In Hawaii, nearly $100 \%$ of the visually inspected mandarin and navel orange trees displayed chlorotic green spots surrounded by yellow haloes (Fig. 3A and $\mathrm{C}$ ). In addition, immature fruit from some navel orange also displayed small (3 to $4 \mathrm{~mm}$ ) chlorotic lesions (Fig. 3B). These symptoms differed from symptoms normally associated with leprosis, lacking brown necrotic spots and necrotic rings. No symptoms were observed in any of the inspected Persian lime trees. Leaves of $H$. tiliaceus displayed symptoms of senescence with patches of lesions with distinct green borders (Fig. 3D). Brevipalpus mites were observed on all tissues (from Colombia, Hawaii, and Mexico). No Brevipalpus mites were observed on the symptomatic H. tiliaceus leaf brought back to the laboratory, although these mites have been occasionally observed on leaves subsequently collected from this same tree.

Molecular identification of leprosis-related viruses. RTPCR assays specific for cytoplasmic and nuclear leprosis viruses were utilized to determine the presence of single or mixed infections of leprosis-associated viruses in rutaceous (mandarin and navel sweet orange and S. glutinosa) and nonrutaceous (Dieffenbachia sp. and $H$. rosa-sinensis) plants in Colombia, Hawaii, and Mexico. CiLV-C2 species specific primers produced amplicons from Dieffenbachia sp., H. rosa-sinensis, and S. glutinosa samples with symptoms of leprosis obtained from Colombia. CiLV-C primers did not produce amplicons when the same RNA templates were used in RT-PCR. CiLV-N specific RT-PCR confirmed the coinfection of CiLV-N and CiLV-C2 in Dieffenbachia sp. and S. glutinosa, but CiLV-N was not detected in $H$. rosa-sinensis plants infected with CiLV-C2. RT-PCR assays for other leprosis-associated viruses did
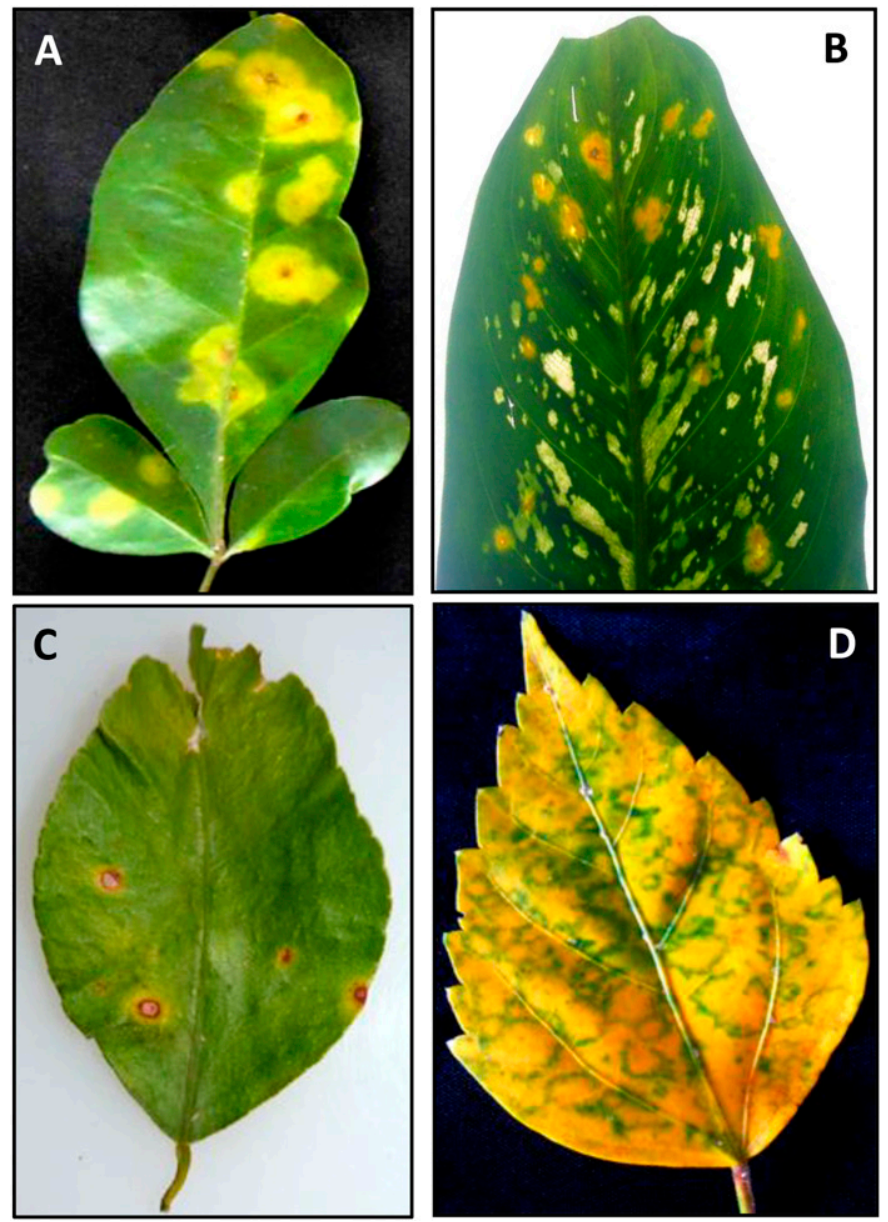

Fig. 2. Natural Citrus leprosis virus $\mathrm{C} 2$ (CiLV-C2) and CiLV-N mixed infection of A, Swinglea glutinosa, and B, Dieffenbachia sp. in Colombia and single infection of $\mathbf{C}$, Persian lime (Citrus latifolia), and D, Hibiscus rosa-sinensis by CiLV-N and CiLV-C2 observed in Mexico and Colombia, respectively. not detect either citrus infecting HGSV-2 or hibiscus infecting Cilevirus in Colombia. The CiLV-N and CiLV-C2 amplicons obtained from Dieffenbachia sp. and S. glutinosa and the CiLV-C2 amplicon from $H$. rosa-sinensis shared 98 to $99 \%$ sequence identity with isolates M2345 of CiLV-N and L147V1 of CiLV-C2, respectively. To test if individual lesions represented single infections within a tree with both viruses, four well separated and one coalesced lesion (consisting of merged single lesions) were collected from three leaves taken from four naturally doubly infected plants from Meta and Casanare and one plant derived by experimental transmission (Fig. 4). RT-PCR from both single and multiple lesions detected both CiLV-C2 and $-\mathrm{N}$ in all of these samples, but no CiLV-C amplicon was ever detected.

Only CiLV-N species specific primers produced amplicons from symptomatic Persian lime leaf samples collected from Querétaro, Mexico. None of the symptomatic tissues collected from leprosisinfected areas of Tabasco and Querétaro state of Mexico produced amplicons in RT-PCR tests with HGSV-2 or hibiscus-infecting cilevirus specific primers. However, both CiLV-C and CiLV-N specific amplicons were obtained from symptomatic sweet orange samples collected from Tabasco, Mexico, where the incidence of CiLV-C was predominant. CiLV-N and CiLV-C amplicons obtained from infections in Persian lime and sweet orange shared 98 to $99 \%$ nucleotide sequence identity with Mexican CiLV-N isolate M2345 (KF209275), strain Jal-1 of CiNSV (KF198064), and Brazilian CiLV-C isolate Cordeiropolis (DQ352194) sequences in GenBank.

In Hawaii, amplification products of the expected size for HGSV-2 were produced from all symptomatic mandarin and navel orange leaf and fruit tissues tested. Amplification products were not observed from either Persian lime leaves or asymptomatic sweet orange fruit rind samples (data not shown). Amplification products from mandarin, sweet orange, and hau ( $H$. tiliaceus) samples were sequenced to identify the presence of HGSV-2. All sequences were $>97 \%$ identical to the HGSV-2 sequence in GenBank (HQ852052).
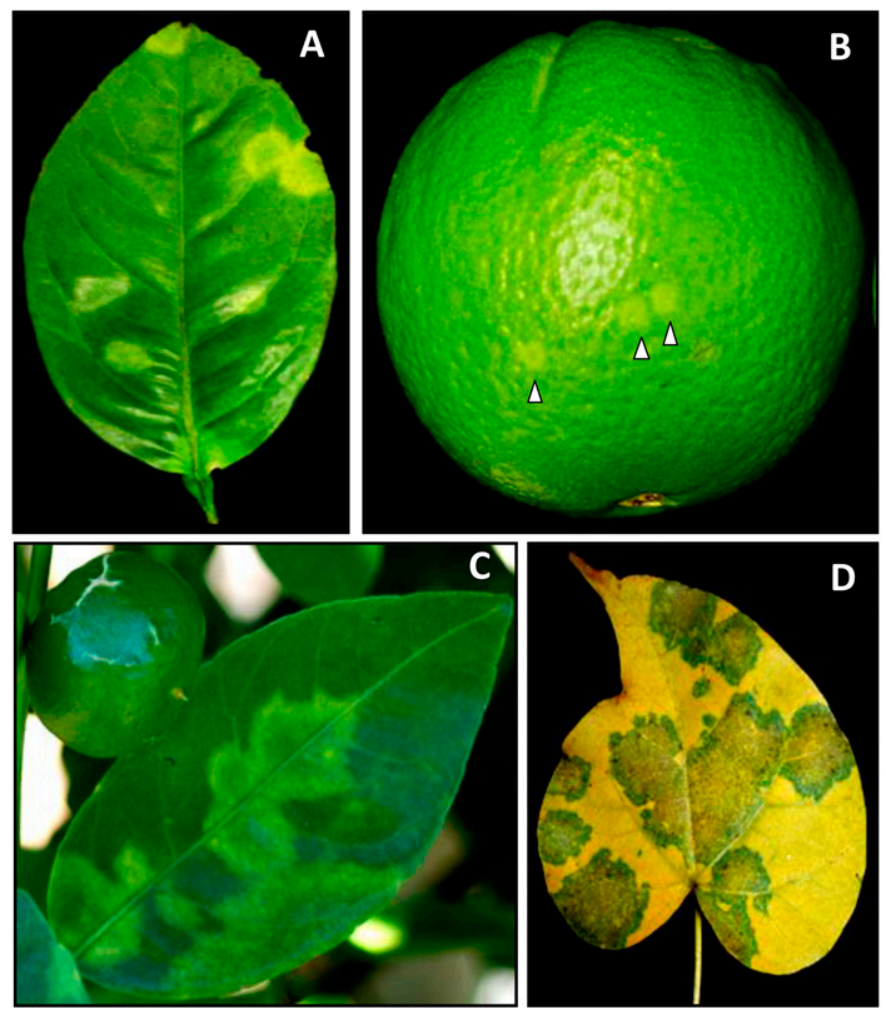

Fig. 3. Natural hosts of Hibiscus green spot virus 2 (HGSV-2) include navel sweet orange (Citrus sinensis) A, leaf, and B, fruit. Arrowheads indicate three lesions on immature fruit. $\mathbf{C}$, Mandarin $(\mathrm{C}$. reticulata) leaf and $\mathbf{D}$, hau ( $\mathrm{Hi}$ biscus tiliaceus) leaf infected by HGSV-2. 
None of the symptomatic Hawaiian samples produced amplicons with either $\mathrm{CiLV}-\mathrm{C},-\mathrm{C} 2$, or $-\mathrm{N}$ specific primers.

Diversity of viruses associated with symptoms of citrus leprosis. The leprosis related positive-sense viruses have either bipartite (CiLV-C and -C2) or tripartite (HGSV-2) genome structures (Fig. 5) and were observed only in the cytoplasm of infected leaf tissues. Leprosis related cileviruses are very distinct from each other (Tables 1 and 2), even though they produce similar leprosis-like symptoms on different citrus species. CiLV-C shared 62 to $77 \%$ and 32 to $40 \%$ (helicase $<\mathrm{RdRP}<$ methyltransferase) sequence identity with $\mathrm{CiLV}-\mathrm{C} 2$ and HGSV-2, respectively. In addition to domains of the replicase polyprotein, p24, a probable integral membrane protein of the virion encoded by RNA2 of CiLV-C and $-\mathrm{C} 2$, shared $26 \%$ nucleotide identity with a similar protein sequence (p23) present in the RNA3 genome of HGSV-2. Further analyses of the p24 or p23 proteins present in these closely related cytoplasmic Brevipalpus mite transmitted or associated plant viruses identified three conserved domains: $\mathrm{A}\left(\mathrm{DX}_{4-5} \mathrm{D}\right), \mathrm{B}\left(\mathrm{GX}_{2-3} \mathrm{TX}_{3} \mathrm{~N}\right)$, and $\mathrm{C}$ (GDD) (data not shown). Interestingly, domains $\mathrm{A}, \mathrm{B}$, and $\mathrm{C}$ were also present either in $\mathrm{ABC}$ or $\mathrm{CAB}$ orientations in several mosquitoborne viruses belonging to the recently proposed taxon Negevirus (Nabeshima et al. 2014).

CiLV-N (Roy et al. 2013b) and CiNSV (Cruz-Jaramillo et al. 2014) share a similar genome structure with Orchid fleck virus (OFV), the type member of the very recently proposed genus Dichorhavirus (Dietzgen et al. 2014) (Fig. 6). The analyses of amino acid similarities (Tables 4 and 5) established a close phylogenetic relationship among CiLV-N, CiNSV, and OFV (Roy et al. 2015). However, information on infection of citrus by OFV or infection of orchids by CiLV-N or CiNSV in nature is not currently available. The partial nucleocapsid gene $(\mathrm{N})$ of $25 \mathrm{CiLV}-\mathrm{N}$ infected tissues from Meta and Casanare states of Colombia and Querétaro
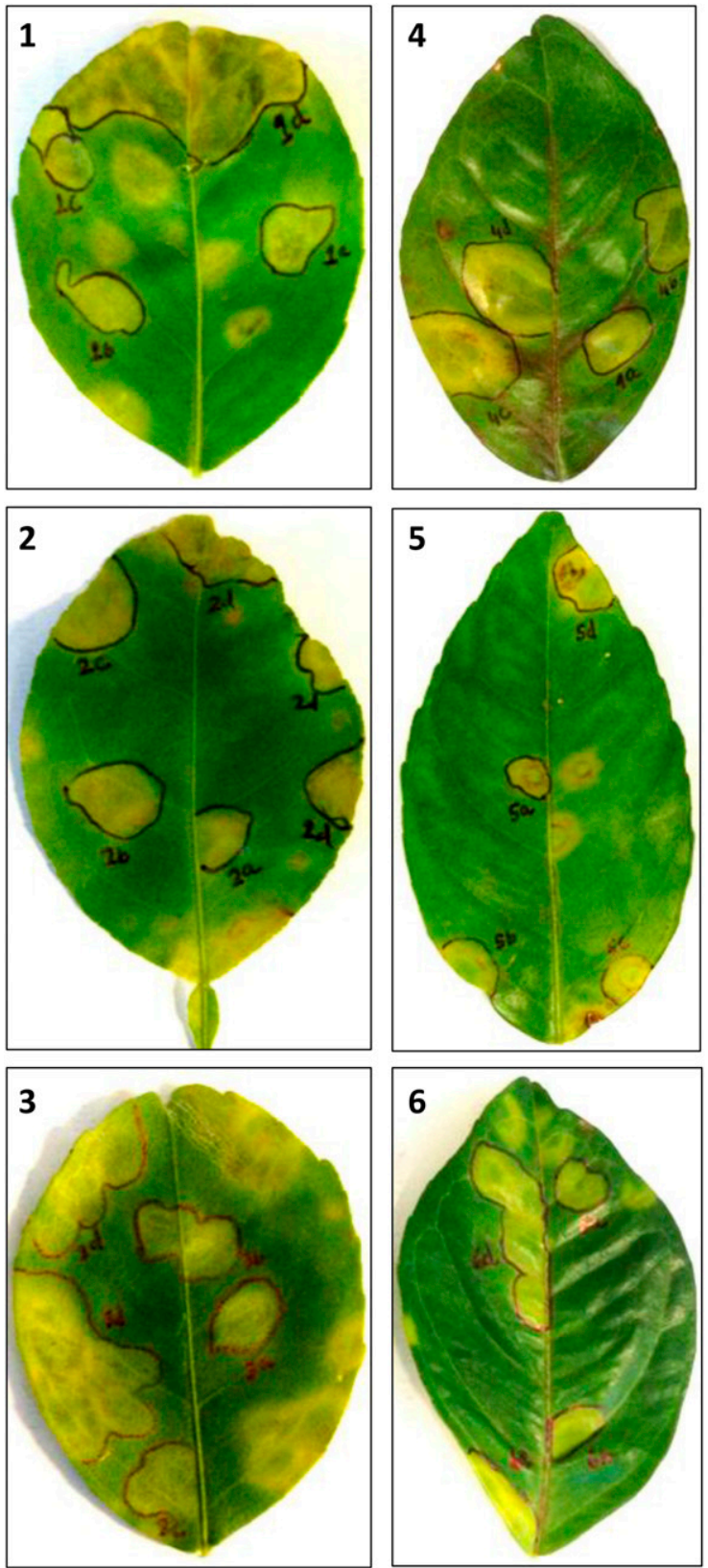
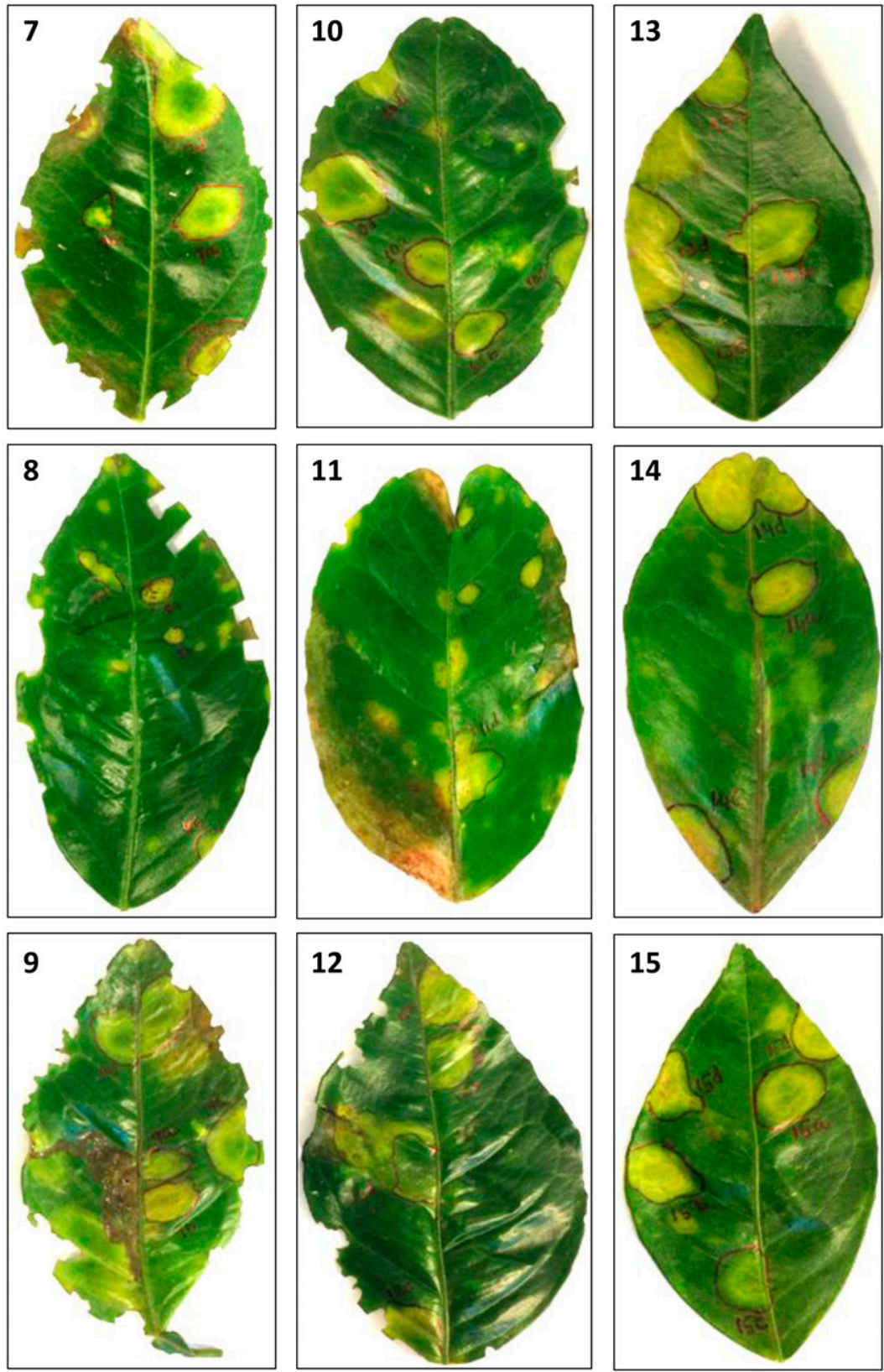

Fig. 4. Detection of cytoplasmic and nuclear citrus leprosis viruses in mixed infection from single and multiple lesions collected from individual field-collected leaves and after successful experimental mite transmission. We choose three leaves from each leprosis-infected citrus plant infected either naturally (4 to 6,7 to 9 , 10 to 12 , and 13 to 15 ) or experimentally ( 1 to 3 ). We marked individual lesions and tested for presence of leprosis viruses using leprosis species specific primers by reverse transcription-polymerase chain reaction. 
state of Mexico were amplified and sequenced. Alignments of the $\mathrm{N}$ gene sequences shared 80 to $99 \%$ sequence identity with the previously reported CiLV-N and CiNSV isolates and formed two separate clusters in the dendogram (data not shown), consistent with the idea that these viruses are somewhat distinct from each other and from OFV.

Virus-mite relationships. All three of the major citrus leprosis viruses (CiLV-C, $-\mathrm{C} 2$, and $-\mathrm{N}$ ) have been reported in the Orinoco region of Colombia. During the survey in 2014, citrus leaves with leprosis symptoms as well as possibly viruliferous mites were collected from citrus groves in Casanare and Meta states, and the virus infection status of both plants and mites was assessed. Both single and multiple leaf lesions collected from leprosis-infected citrus groves were infected with both CiLV-C2 and CiLV-N (Fig. 4). RT-PCR using RNA from batched potentially viruliferous field collected mites also identified CiLV-C2 and CiLV-N in the mites. Surprisingly, CiLV-C, which is less prevalent in this region, was detected in the field collected mites. This is the first record of detection of all three leprosis viruses in Brevipalpus mites collected from the same area. In another experiment, viruliferous fieldcollected mites (confirmed by RT-PCR) were fed on leaves of healthy sweet orange seedlings. Virus-free Brevipalpus mites were also fed on field plants infected with CiLV-C2 and CiLV-N, and then used to inoculate healthy sweet orange seedlings. Four to six weeks after mite transfer, leprosis symptoms developed on healthy sweet orange leaves (Fig. 4). Small circular chlorotic spots were observed initially and over time each spot increased in size and coalesced into large chlorotic areas 110 to 120 days after the inoculation access period (IAP). Interestingly, both inoculation treatments generated mixed infections of CiLV-C2 and CiLV-N. None of the leprosis symptomatic plants became positive for CiLV-C.

In mite surveys, $B$. californicus s.l. associated with citrus in Mexico was found mainly at higher elevations, between 1,500 and 2,200 $\mathrm{m}$ above sea level (masl), in the central Mexican plateau, and was the only Brevipalpus species present at these altitudes (Fig. 7A and G). However, B. californicus s.l. was also collected in Tamaulipas State, at about 150 masl. Salinas-Vargas et al. (2013) identified B. californicus s.l. on citrus, coexisting with $B$. phoenicis s.l.,

A

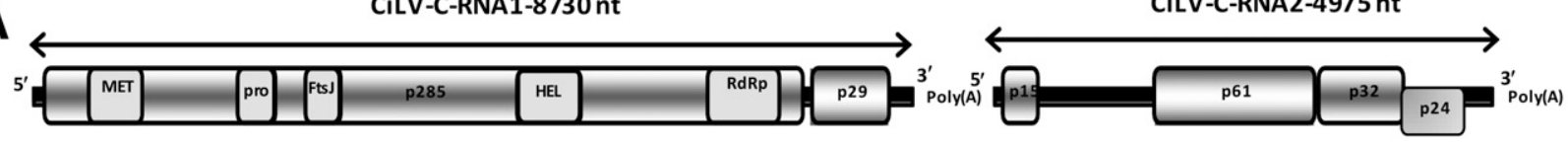

B

CiLV-C2-RNA1-8717 nt

CiLV-C2-RNA2-5093 nt

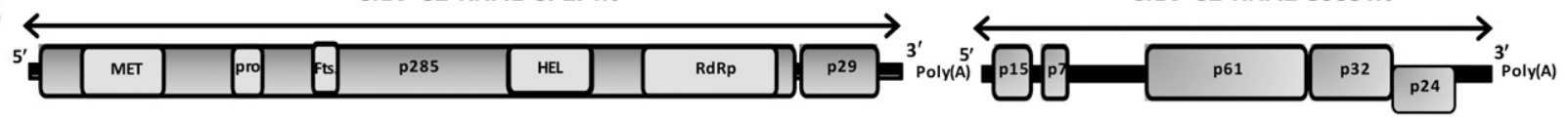

C

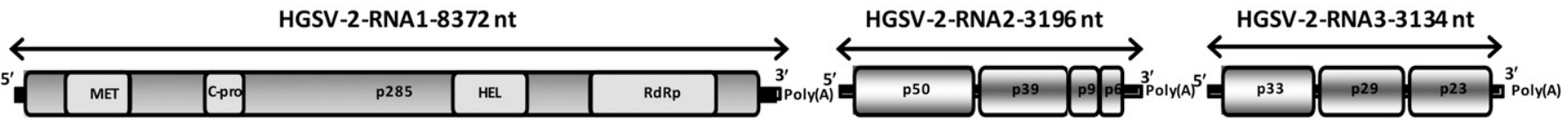

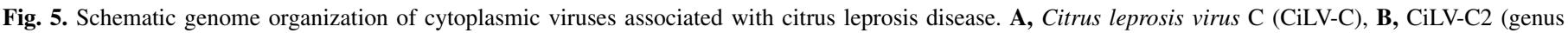
Cilevirus), and $\mathbf{C}$, Hibiscus green spot virus 2 (HGSV-2) (genus Higrevirus).

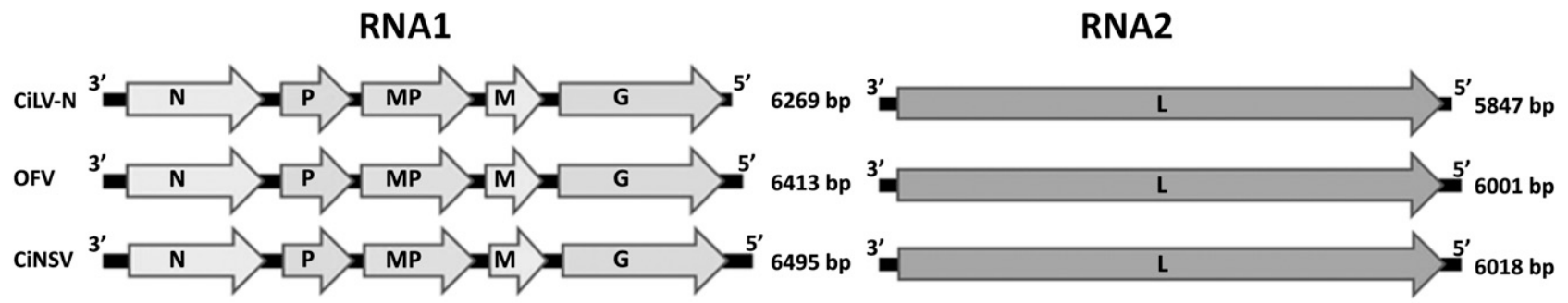

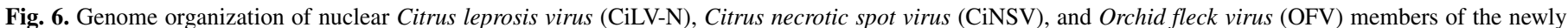

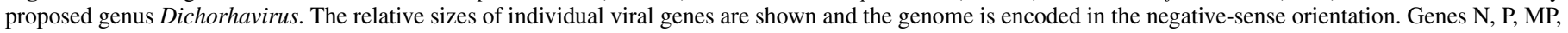
M, G, and L encode nucleocapsid-, phospho-, movement-, matrix-, glyco-, and long polymerase proteins, respectively.

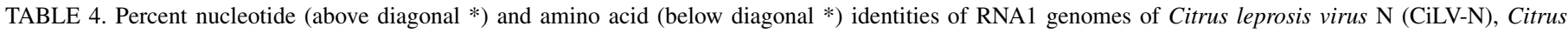
necrotic spot virus (CiNSV), and Orchid fleck virus (OFV) associated with leprosis-like symptoms ${ }^{\mathrm{a}}$

\begin{tabular}{|c|c|c|c|c|c|c|c|c|c|c|c|c|c|c|c|c|c|c|c|}
\hline \multirow[b]{3}{*}{ SI number } & \multirow[b]{3}{*}{ Viruses } & \multicolumn{15}{|c|}{ RNA1 } & & & \\
\hline & & \multicolumn{3}{|c|}{ ORF1 (p49) } & \multicolumn{3}{|c|}{ ORF2 (p27) } & \multicolumn{3}{|c|}{ ORF3 (p42) } & \multicolumn{3}{|c|}{ ORF4 (p20) } & \multicolumn{3}{|c|}{ ORF5 (p63) } & \multicolumn{3}{|c|}{ Complete genome } \\
\hline & & 1 & 2 & 3 & 1 & 2 & 3 & 1 & 2 & 3 & 1 & 2 & 3 & 1 & 2 & 3 & 1 & 2 & 3 \\
\hline 1 & CiLV-N & $*$ & 97 & 90 & $*$ & 96 & $92-93$ & $*$ & 96 & 90 & $*$ & 97 & $89-90$ & $*$ & 96 & 88 & $*$ & 93 & 88 \\
\hline 2 & CiNSV & 98 & $*$ & 90 & 97 & $*$ & 93 & 95 & $*$ & 90 & 96 & $*$ & 90 & 96 & $*$ & 88 & ND & $*$ & 88 \\
\hline 3 & $\mathrm{OFV}$ & $97-98$ & $97-98$ & $*$ & 97 & 97 & $*$ & 93 & 93 & $*$ & $93-94$ & 97 & $*$ & 92 & 92 & $*$ & ND & ND & $*$ \\
\hline
\end{tabular}

a ND indicates data not determined. 
at several locations on the Yucatán Peninsula, at less than 100 masl, and De Leon (1961) reported B. californicus s.l. associated with citrus at about 450 masl in Montemorelos, Nuevo Leon State, Mexico. In contrast, B. yothersi was prevalent in lowlands (less than 100 masl), throughout both the Pacific and the Atlantic Coastal plains, although this species was also collected in Morelos state, at about 1,000 masl (Fig. 7B and G). De Leon (1961) identified B. phoenicis s.l. in several Mexican lowland localities. Later Izquierdo Castillo et al. (2011) also identified B. phoenicis s.l. mites as the only Brevipalpus species found associated with leprosis in the lowlands of Tabasco and Chiapas states.

Our study of this material, utilizing multiple distinguishing characters (Table 3 ) including cuticular microplates (Fig. 7D to E), indicates that the Mexican species previously identified as B. phoenicis s.l. (i.e., a member of the $B$. phoenicis species group) is actually $B$. yothersi. The true B. phoenicis sensu stricto, while recorded on Citrus spp. hosts, has not yet been associated with citrus leprosis (Beard et al. 2015). Collections of Brevipalpus mites from Colombia, Brazil, and Mexico found two different Brevipalpus species, in two different species groups, associated with citrus leprosis, B. yothersi (B. phoenicis species group: tarsus II with two solenidia; dorsal seta $f 2$ absent) and $B$. californicus s.l. (B. californicus species group: tarsus II with two solenidia; dorsal seta $f 2$ present). Here, the species collected in association with the cytoplasmatic type of citrus leprosis virus from Colombia, Brazil, Mexico, and Panama (G. Leon, J. Mineiro, G. Otero-Colina, and R. H. Brlansky, personal observations) has been identified as B. yothersi, a former synonym of B. phoenicis (Geijskes) (Fig. 7A). B. obovatus was not found in these surveys. Together with elevation data, this indicates that B. californicus s.l. thrives mostly in temperate places when associated with citrus, while $B$. yothersi prefers warmer localities. Either species may be present at intermediate altitudes. In Mexico, nuclear viruses are most prevalent at high altitudes or in temperate localities, associated with B. californicus s.l., and cytoplasmic viruses are most prevalent in warm lowland regions, where $B$. yothersi is the most abundant species.

Phylogenetic analyses. Phylogenetic analyses of the RdRp2 domain and the p 24 protein of cileviruses, several insect viruses and several insect-transmitted plant viruses were constructed with the neighbor joining method. The RdRp2 domain, deduced from the amino acid sequence of the replicase gene, is present in a diverse set of plant and insect viruses. The RdRp phylogeny included several clades and overall the bootstrap values within each of the clades (Cilevirus, Negevirus, and Blunervirus) were very strong, ranging from 86 to 100 (Fig. 8A). Negeviruses formed a sister clade with cileviruses, including CiLV-C, but with a bootstrap value of only 70 , consistent with unknown common ancestors. Interestingly, within the cilevirus clade, CiLV-C2 shared a common ancestor with the hibiscus-infecting cilevirus, and along with Lingustrum ringspot virus formed a sister clade with CiLV-C, with a bootstrap value of 100. A similar tree topology was displayed when the helicase domain protein sequences were aligned and compared (data not shown).

The p24 genes of the cilevirus group are novel, and many plant viruses do not have this type of p24 gene (Kuchibhatla et al. 2014). In addition, some other groups did not annotate homologous

TABLE 5. Percent nucleotide (above diagonal *) and amino acid (below diagonal *) identities of RNA2 genomes of Citrus leprosis virus N (CiLV-N), Citrus necrotic spot virus (CiNSV), and Orchid fleck virus (OFV) associated with leprosis-like symptoms ${ }^{\mathrm{a}}$

\begin{tabular}{|c|c|c|c|c|c|c|c|}
\hline \multirow[b]{3}{*}{ SI number } & \multirow[b]{3}{*}{ Viruses } & \multicolumn{3}{|c|}{ RNA2 } & & & \\
\hline & & \multicolumn{3}{|c|}{ ORF1 (p212) } & \multicolumn{3}{|c|}{ Complete genome } \\
\hline & & 1 & 2 & 3 & 1 & 2 & 3 \\
\hline 1 & CiLV-N & $*$ & 96 & $89-90$ & $*$ & 93 & $87-88$ \\
\hline 2 & CiNSV & 97 & $*$ & $88-89$ & ND & $*$ & $88-89$ \\
\hline 3 & OFV & 97 & $95-96$ & $*$ & ND & ND & $*$ \\
\hline
\end{tabular}

a ND indicates data not determined. sequences as p24 genes. Therefore only a handful of $\mathrm{p} 24$ proteins of this type are annotated in GenBank and other publically available databases. Advanced homology detection methods such as HHblits and HHpred (Kuchibhatla et al. 2014) were utilized to identify p24 genes in virus sequences available in the GenBank, including remote homologs of the p24 gene of the cilevirus group (Blastp e-04 to -31). Examination of the p24 tree showed that the genera Cilevirus and Higrevirus were well separated from the mosquito viruses. The speciation event that separated the cilevirus and higrevirus groups from the blunervirus and negevirus groups had a strong bootstrap value of 92 (Fig. 8B).

CiLV-N and CiNSV shared a very similar overall genome structure with OFV, the type member of the proposed genus Dichorhavirus, as well as with the recently sequenced Coffee ring spot virus (Ramalho et al. 2014). Nucleocapsid (N), glycoprotein $(\mathrm{G})$, and long polymerase (L) genes from these genomes, conserved among all the members of the family Rhabdoviridae, had the greatest regions of similarity irrespective of plant hosts. Phylogenetic analysis of the N, G, and L genes calculated with the neighborjoining method clearly showed that CiLV-N and CiNSV were distinct members of the genus Dichorhavirus, as they were found on separate branches from that occupied by OFV (data not shown). In contrast, an analysis of a phylogenetic tree calculated from the same sequence data with the maximum parsimony method was consistent with the interpretation that CiLV-N and CiNSV were citrus strains of OFV rather than a distinct virus (data not shown). Final taxonomic classification of CiLV-N and CiNSV will remain unclear until sequence data from more CiLV-N and CiNSV isolates are available.

Replication of CiLV-C, CiLV-C2, and CiLV-N inside mites. Based on the identifications of mites from leprosis-affected areas in Colombia and Mexico, the two most important species of the genus Brevipalpus for CiLV transmission, B. yothersi and B. californicus s.l., were assessed for the replication of CiLV-C, -C2, and $-\mathrm{N}$. The Orinoco region of Colombia is the only place where all three types of citrus leprosis viral pathogens are known to be present. To determine whether $\mathrm{CiLV}-\mathrm{C},-\mathrm{C} 2$, and $-\mathrm{N}$ replicate inside Brevipalpus spp., an RT-PCR assay specific for the replicative strand of viral RNA was designed to detect the presence of the positive-sense (for CiLV-N) or negative-sense (CiLV-C and -C2) RNA strand inside the mite. RNA was extracted from Brevipalpus mites collected from leprosis-infected citrus groves in Meta, Colombia, and the same RNA templates were utilized to make cDNA with leprosis virus species specific replicative strand primers.

A positive-sense strand specific PCR amplicon specific for CiLV-C and CiLV-C2 and a negative-sense strand specific PCR amplicon specific for CiLV-N were obtained from potentially viruliferous mites, confirming the presence of cytoplasmic and nuclear leprosis virions in the mites. In parallel, negative and positive strand specific PCR for cytoplasmic (CiLV-C and -C2) and nuclear (CiLV-N) leprosis viruses, respectively, generated replicative strand specific amplicons for CiLV-C, CiLV-C2, and CiLV-N from the same RNA template, confirming the presence of replication intermediates inside the mites. Both positive and negative strand specific RT-PCR assays performed without prior RT failed to produce any amplicons (Fig. 9).

\section{DISCUSSION}

Presently, five well-defined viruses are associated with citrus leprosis syndrome in the Americas. Three of them, CiLV-C (LocaliFabris et al. 2006; Pascon et al. 2006), CiLV-C2 (Roy et al. 2013a), and HGSV-2 (Melzer et al. 2012), produce particles primarily in the cytoplasm of infected cells, and the remaining two viruses CiLV-N (Roy et al. 2013b) and CiNSV (Cruz-Jaramillo et al. 2014) produce particles primarily in the nucleus of infected cells. The 
viruses associated with leprosis are clearly an emerging issue, as the distribution within the new world seems to be expanding rapidly (Fig. 1).

The plant host situation for leprosis-related viruses is rather unique. No systemic plant hosts have been identified for any of the viruses associated with citrus leprosis. Very recently, in an experimental host range study for CiLV-C, 140 species from 43 families were tested (Garita et al. 2014), and 40 species belonging to 18 families produced either localized chlorotic and/or necrotic lesions on leaves and were PCR-positive for CiLV-C. Dieffenbachia sp. had never been considered as experimental host for CiLV-C, but survey work in Colombia demonstrated that CiLV-C2 infects Dieffenbachia sp., S. glutinosa, and H. rosa-sinesis (Fig. 2). RT-PCR was used to determine that sweet orange, Dieffenbachia sp., and S. glutinosa in
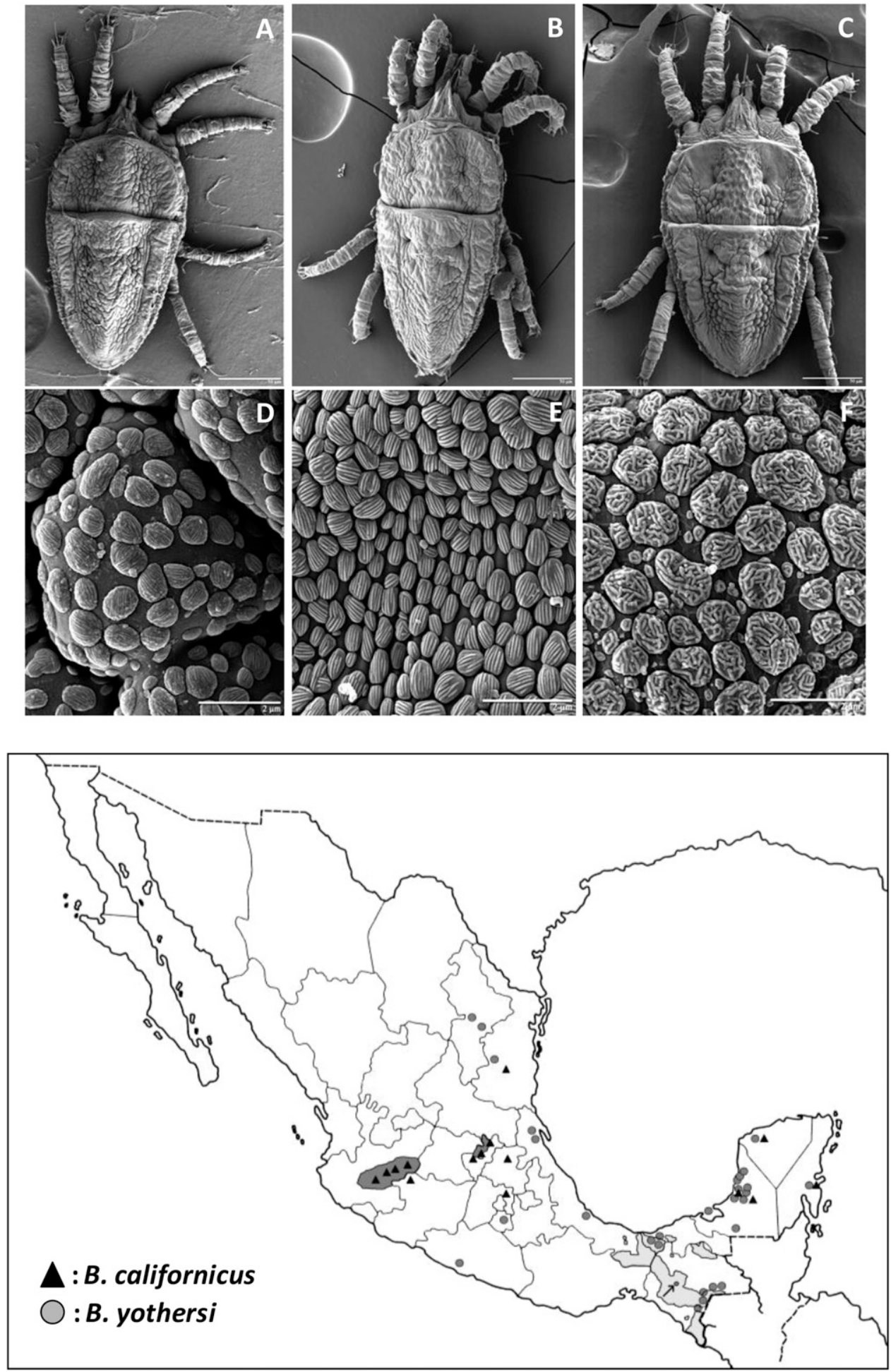

Fig. 7. Morphological identification of Brevipalpus species associated with Citrus leprosis virus C (CiLV-C) and CiLV-N using low temperature scanning electron microscopy. Habitus images of A, B. californicus sensu lato (s.1.), B, B. yothersi, C, B. phoenicis sensu strict (s.s.). Pattern of cuticular microplates of D, B. californicus s.1., E, B. yothersi, and F, B. phoenicis s.s. While B. phoencis s.s. has been recorded from different Citrus spp., it has never been associated with citrus leprosis, and is included here only to indicate the differences between it and its former synonym $B$. yothersi. Bottom image shows the distribution of both Brevipalpus species in leprosis-free and -affected areas in Mexico. Regions in light and dark gray colors represent the presence of cytoplasmic and nuclear type, respectively. The arrow in light gray area indicates the presence of nuclear type in the state of Chiapas, Mexico. 
Colombia were infected by CiLV-C2 and CiLV-N in mixed infections. This is the first report of natural infection of leprosis viruses on Dieffenbachia. Examination of individual lesions indicated that both viruses were frequently found in the same lesion, suggesting that both viruses may co-occur in individual mites without interfering with each other during infection. The amplified product from $H$. rosa-sinensis had a $99 \%$ sequence identity with CiLV-C2. H. rosa-sinensis has also been reported as experimental host for CiLV-C (Nunes et al. 2012b).

The previously dominant leprosis species, CiLV-C (Leon et al. 2006a, b), was not detected in Meta and Casanare, Colombia
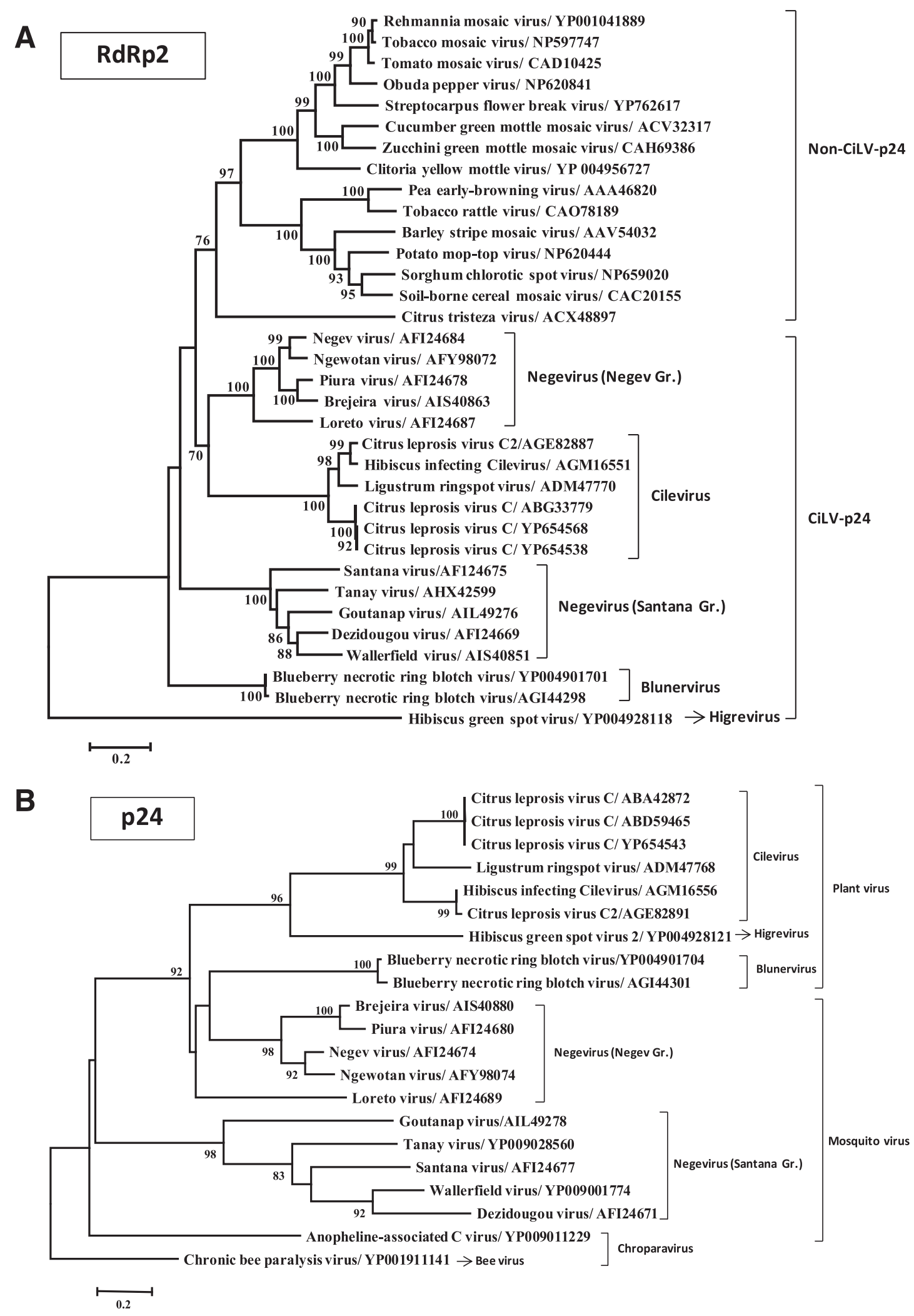

Fig. 8. Phylogenies produced using neighbor-joining methods based on genome sequence of leprosis-associated viruses with related plant and insect viruses. A, RNA dependent RNA polymerase 2 (RdRp2) from RNA1, and B, with probable internal membrane protein of the virion (p24) from RNA2 or RNA3. Phylogenies were supported by 1,000 bootstrap replicates and bootstrap values greater than 70 are shown at the nodes. 
(Roy et al. 2013a). Surprisingly, CiLV-C, -C2, and -N were all detected inside the viruliferous mites collected from the Orinoco region of Colombia. Mite transmission experiments conducted using healthy mites and mixed infections of $\mathrm{CiLV}-\mathrm{C} 2$ and $-\mathrm{N}$ viruses as a source of inoculum were successful for CiLV-C2 and -N. In parallel experiments using field-collected viruliferous mites positive for CiLV-C, $-\mathrm{C} 2$, and $-\mathrm{N}$, the mites transmitted CiLV-C2 and CiLV-N but failed to transmit CiLV-C to healthy seedlings. This suggests that the previously predominant leprosis species CiLV-C in Colombia may be replaced by the presently dominant leprosis species CiLV-C2, perhaps due to selective advantage or preference conferred during the mite transmission to plants (Roy et al. 2013a). In an effort to find CiLV-C in Colombia, some municipalities of Tolima, Cundinamarca, and Vichada States in Colombia were also surveyed during 2013 and 2014. Suspected leprosis lesions found in C. sinensis and S. glutinosa in Tolima and Cundinamarca States and in $C$. sinensis in the State of Vichada tested positive for CiLV-C2 and CiLV-N (Fig. 1C). The absence of CiLV-C in these locations further suggested that CiLV-C is being replaced by CiLV-C2. However, single mite acquisition tests, currently limited by the sensitivity of RT-PCR assays, will be needed to test the hypothesis that mite acquisition is related to the replacement of CiLV-C by CiLV-C2.

Previously, HGSV-2 had only been reported in C. volkameriana and $H$. arnottianus, two species of limited agricultural importance. C. volkameriana's primary importance to the citrus industry is as a rootstock, and therefore its susceptibility to the nonsystemic HGSV-2 in leaf and twig tissue is not a concern. Field surveys in Hawaii demonstrated that the host range of HGSV-2 includes mandarin and navel orange, as well as a common landscape tree, H. tiliaceus (Fig. 3). However, even though nearly $100 \%$ of the mandarin and navel orange trees displayed symptoms, the adjacent Persian lime trees were asymptomatic and virus-free.

Less is known about the host range of CiLV-N. CiLV-N was reported from Querétaro state, Mexico in 2013 and leprosis symptoms were observed on seven naturally infected citrus species in that state (grapefruit, lime, lemon, mandarin, sour orange, sweet lime, and sweet orange) (Roy et al. 2015). Similarly, CiNSV was also reported from grapefruit, sour orange, sweet orange and tangerine in Jalisco, Mexico (Cruz-Jaramillo et al. 2014). To determine the distribution and genetic variability among CiLV-N isolates a survey was conducted in June 2014. Apart from the seven previously reported citrus hosts for CiLV-N, Persian lime also displayed distinct necrotic rings surrounded by yellow haloes (Fig. 2C). RT-PCR confirmed the presence of CiLV-N, extending the agricultural host list within Citrus.

A careful examination of Brevipalpus mites from Colombia, Brazil, and Mexico found B. yothersi and B. californicus s.l. associated with citrus leprosis (Fig. 7A and B). The mite species collected in association with the cytoplasmatic type of CiLV from Colombia, Brazil, Mexico, and Panama has been identified as B. yothersi, former synonym of B. phoenicis (Pritchard and Baker 1952) (Fig. 7A and B). B. yothersi was listed by Beard et al. (2013) as $B$. phoenicis group species B. However, based on a detailed examination of specimens of several species (including type material) in the $B$. phoenicis complex using LT-SEM and traditional light microscopy, $B$. yothersi was reinstated as a valid species and redescribed (Beard et al. 2015) and is considered to be a recognized vector of the citrus leprosis complex. The discovery of the presence of specific patterns of microplates (Welbourn et al. 2003) on the cuticle of Brevipalpus mites has proven to be critical for species separation and confirmation within this genus.

In Mexico two mite species were identified, $B$. yothersi associated with CiLV-C and B. californicus s.l. associated with CiLV-N. There are also two reports from Tabasco (G. Otero-Colina, personal communication) of CiLV-N or CiNSV in mixed infections with the prevalent CiLV-C population. As the co-occurrence of $B$. yothersi and B. californicus s.l. in southern Mexico has not been documented, we suggest that both cytoplasmic and nuclear leprosis viruses may be transmitted by $B$. yothersi. Based on RT-PCR results, the lower concentration of CiLV-N than CiLV-C was observed in symptomatic leprosis tissues, suggesting that $B$. yothersi may possibly acquire and transmit CiLV-C more efficiently than it does CiLV-N. Further experiments on CiLV transmission followed by detection and quantification of individual leprosis virus species using both $B$. californicus s.l. and B. yothersi will provide a better understanding of virus-vectors relationships.

The lack of a natural systemic plant host is quite atypical for plant viruses, raising the question of whether or not these two completely unrelated virus groups are actually insect viruses that have convergently evolved a unique approach for mite-to-mite transmission. There is evidence for a relationship between CiLV-N and mites, as electron lucent viroplasm and rod shaped particles of

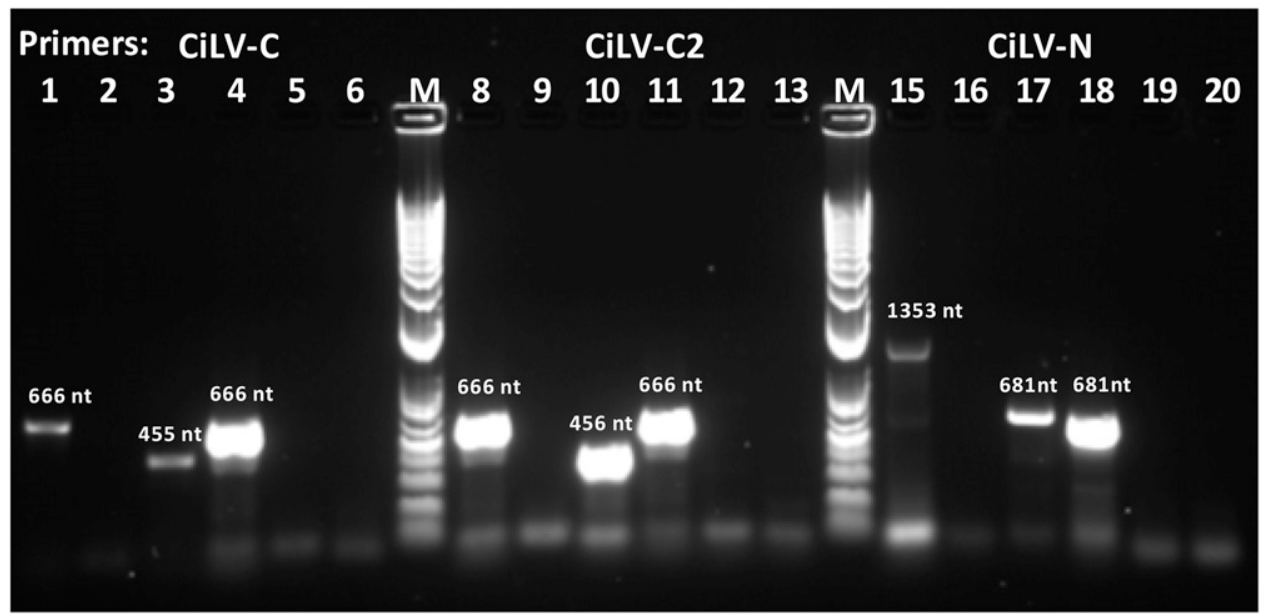

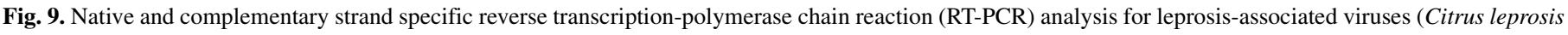

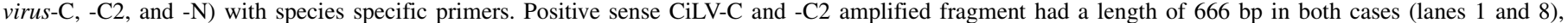

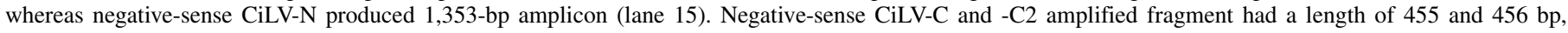

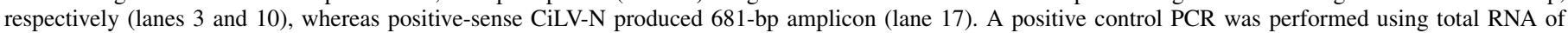

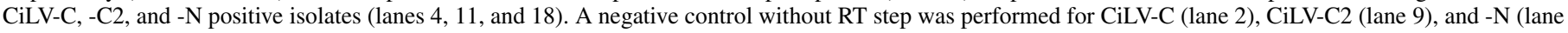

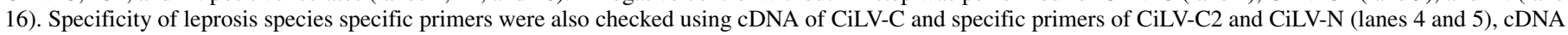

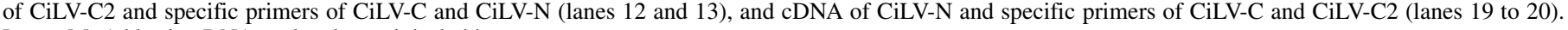
Lanes M: 1-kb plus DNA molecular weight ladder. 
CiLV-N were found in cytoplasm as well as in the nucleus of the viruliferous Brevipalpus mites. These cytopathic effects are similar to what was observed in CiLV-N infected plant tissues, suggesting that the CiLV-N is replicating inside the mite cells (Kitajima and Alberti 2014). This is not surprising, as there are a fair number of rhabdoviruses that infect both plants and insects (Ammar et al. 2009).

The situation is much less clear for cileviruses. CiLV-C was first observed in thin sections of viruliferous B. phoenicis s.l. utilizing TEM (Rodrigues et al. 1997). However, Kitajima et al. (2014) suggested that the previously described image of CiLV-C in $B$. phoenicis was misinterpreted. Based on our identification criteria, we strongly suspect that the species used by Rodrigues et al. (1997) and Kitajima et al. (2014) is B. yothersi. Recently Kitajima and Alberti (2014) showed CiLV-C particles persistently present in mites, between membranes of adjacent cells, particularly at the basal parts of the midgut epithelium and neighbor cells. In contrast, CiLV-N particles were present in many nuclei of cells of the anterior midgut epithelium, anterior podocephalic glands, and epidermis. TEM of thin sections was unable to find intracellular viral particles and viroplasms of CiLV-C in mites, indicating that CiLV-C may not be replicating inside the mite cells.

Despite this, phylogenetic analyses suggested that there may be a relationship between cytoplasmic leprosis-associated viruses and insect viruses. The phylogeny derived from the helicase and RdRp2 domains separates the non-CiLV group of plant viruses, which lack a p24 gene, and the cilevirus group that contain a p24 gene. Overall, the independent phylogenetic tree calculated from the p24 protein sequences was very consistent with the phylogenetic trees calculated from the helicase and RdRp2 domain, with similar topologies within the cilevirus clade (Fig. 8). Taken together, Brevipalpus mitetransmitted or associated viruses from the genera Cilevirus, Higrevirus, and Blunervirus are more closely related to the insect viruses than to other plant viruses. The tree calculated from the RdRp2 domain shows a clear separation of the plant and insect viruses, but with the cilevirus clade clustering within the insect virus group.

The $\mathrm{p} 24$ proteins of cileviruses, higrevirus, and blunervirus have four transmembrane domains and this class of $\mathrm{p} 24$ proteins probably acts as a major structural component of the virion (Kuchibhatla et al. 2014). The members of the genera Cilevirus and Higrevirus produce bacilliform particles, while members of the genus Negevirus produce spherical particles, and the viruses were separated in the p24 tree into sister clades consistent with this particle morphology. In addition, the CiLV-C and CiLV-C2 have a p24 protein that is related to the p24 protein from the insect viruses. This suggests that the cilevirus group may have originated in the mite, and has secondarily adapted to the plant host, perhaps conferring the role of vector on the plant in this unusual plant virus system. Data consistent with virus replication in mites were obtained for CiLV-C and CiLV-C2 as well as CiLV-N. Negative strand RNAs for the positive sense viruses (CiLV-C and -C2) and positive strand RNAs for negative sense viruses (CiLV-N), known to function as replication intermediates, were detected inside B. yothersi. Additionally, examination of single lesions simultaneously infected with both virus types suggest that individual mites may be coinfected with multiple leprosis-related viruses, because it is assumed that the single lesion is derived from a single feeding mite, although it is not clear whether these viruses infect and utilize the same tissues within the mite. The effect of leprosis-related virus coexistence in single mites in terms of synergy, transmissibility, symptoms, virus replication, and life expectancy of Brevipalpus species remains unclear. Regardless, these viruses seem to have convergently evolved a unique approach for mite-to-mite transmission that warrants further study.

\section{ACKNOWLEDGMENTS}

We thank D. Creel and N. Malikul (SEL-USDA), J. Mineiro, M. Sato, A. L. Matioli (Laboratorio de Acarologia, Centro Experimental do Instituto Biologico, Brazil), and J. E. Peña (Tropical Research and Education Center, University of Florida) for their continued support with Brevipalpus spp. specimen preparation, and data and reference collection. We thank A. Stone (FDWSRU, Ft. Detrick, MD) for his technical help and C. Pooley (E\&CMU USDA-ARS) and C. Paul (EPCC, USDA-ARS), Beltsville, MD, for figure preparations. This research was financially supported by the USDAAPHIS-PPQ and the Citrus Research and Development Foundation Grant 405.

\section{LITERATURE CITED}

Ammar, E. D., Tsai, C. W., Whitfield, A. E., Redinbaugh, M. G., and Hogenhout, S. A. 2009. Cellular and molecular aspects of rhabdovirus interactions with insect and plant hosts. Annu. Rev. Entomol. 54:447-468.

Bastianel, M., Novelli, V. M., Kitajima, E. W., Kubo, K. S., Bassanezi, R. B., Machado, M. A., and Freitas-Astúa, J. 2010. Citrus leprosis: Centennial of an unusual mite-virus pathosystem. Plant Dis. 94:284-292.

Beard, J. J., Ochoa, R., Bauchan, G. R., and Braswell, W. E. 2014. Brevipalpus phoenicis (Geijskes) species complex-Resurrection of E.W. Baker's species (Acari: Tenuipalpidae). XIV International Congress of Acarology 60, Acarology Soc. Japan, Kyoto, Japan.

Beard, J. J., Ochoa, R., Bauchan, G. R., Trice, M., Redford, A., Walters, T., and Mitter, C. 2013. Flat Mites of the World. USDA Center for Plant Health Science and Technology, University of Maryland, and the USDA-ARS, Systematic Entomology Laboratory. http://idtools.org/id/mites/flatmites/

Beard, J. J., Ochoa, R., Braswell, W. E., and Bauchan, G. R. 2015. Brevipalpus phoenicis (Geijskes) species complex: A closer look. Zootaxa 3944(1):1-67.

Bitancourt, A. A. 1934. Relação das doenças e fungos parasitas observados na secção de fitopatologia durante os anos de 1931 e 1932. Arq. Inst. Biol. (Sao Paulo) 5:185-196.

Bitancourt, A. A. 1940. A leprose dos citrus. O Biol. 6:39-45.

Bolton, S. J., Klompen, H., Bauchan, G. R., and Ochoa, R. 2014. A new genus and species for Nematalycidae (Acari: Endeostigmata). J. Nat. Hist. 48:1359-1373.

Childers, C. C., and Derrick, K. S. 2003. Brevipalpus mites as vectors of unassigned rhabdoviruses in various crops. Exp. Appl. Acarol. 30:1-231.

Childers, C. C., Rodrigues, J., Derrick, K., Achor, D., French, J., Welbourn, W., Ochoa, R., and Kitajima, E. W. 2003a. Citrus leprosis and its status in Florida and Texas: Past and present. Exp. Appl. Acarol. 30:181-202.

Childers, C. C., Rodriguez, J., and Wellbourn, W. 2003b. Host plants of Brevipalpus californicus, B. obovatus, and B. phoenicis (Acari: Tenuipalpidae) and their potential involvement in the spread of viral diseases vectored by these mites. Exp. Appl. Acarol. 30:29-105.

Colariccio, A., Lovisolo, O., Chagas, C. M., Galletti, S. R., Rossetti, V., and Kitajima, E. W. 1995. Mechanical transmission and ultrastructural aspects of citrus leprosis disease. Fitopatol. Bras. 20:208-213.

Cruz-Jaramillo, J. L., Ruiz-Medrano, R., Rojas-Morales, L., Lopez-Buenfil, J. A., Morales-Galvan, O., Chavarin-Palacio, C., Ramirez-Pool, J. A., and Xoconostle-Cazares, B. 2014. Characterization of a proposed dichorhavirus associated with the citrus leprosis disease and analysis of the host response. Viruses 6:2602-2622.

De Leon, D. 1961. New false spider mites with notes on some previously described species (Acarina: Tenuipalpidae). Fla. Entomol. 44:167-178.

Dietzgen, R. G., Kuhn, J. H., Clawson, A. N., Freitas-Astua, J., Goodin, M. M., Kitajima, E. W., Kondo, H., Wetzel, T., and Whitfield, A. E. 2014. Dichorhavirus: A proposed new genus for Brevipalpus mite-transmitted, nuclear, bacilliform, bipartite, negative-strand RNA plant viruses. Arch. Virol. 159:607-619.

Frezzi, M. J. 1940. La lepra explosiva del naranjo. Min. Agric. Nacion. Bol. Frutas y Hortalizas, Buenos Aires.

Garita, L. C., Tassi, A. D., Calegario, R. F., Freitas-Astúa, J., Salaroli, R. B., Romão, G. O., and Kitajima, E. W. 2014. Experimental host range of Citrus leprosis virus $C$ (CiLV-C). Trop. Plant Pathol. 39:43-55.

Garita, L. C., Tassi, A. D., Calegario, R. F., Kitajima, E. W., Carbonell, S. A. M., and Freitas-Astúa, J. 2013. Common bean (Phaseolus vulgaris L.): Experimental local lesion host for Citrus leprosis virus $C$ (CiLV-C) and some other cytoplasmic-type Brevipalpus-transmitted viruses. Plant Dis. 97:1346-1351.

Groot, T. V. M., Freitas-Astúa, J., and Kitajima, E. W. 2006. Brevipalpus phoenicis transmits citrus leprosis virus, cytoplasmic type (CiLV-C) to common bean (Phaseolus vulgaris) under experimental conditions. Virus Rev. Res. 11:67-68.

Izquierdo-Castillo, I., Zermeño-Díaz, L. F., Méndez, W., Otero-Colina, G., Freitas-Astúa, J., Locali-Fabris, E. C., de Moraes, G. J., Calegario, R. F., Tassi, A. D., and Kitajima, E. W. 2011. Confirmation of the presence of the Citrus leprosis virus C (CiLV-C) in Southern Mexico. Trop. Plant Pathol. 36:400-403.

Kitajima, E. W., and Alberti, G. 2014. Anatomy and fine structure of Brevipalpus Mites (Tenuipalpidae) - economically important plant-virus vectors - Part 7: Ultrastructural detection of cytoplasmic and nuclear types of Brevipalpus-transmitted viruses. Pages 173-192 in: Anatomy and Fine Structure of Brevipalpus Mites (Tenuipalpidae) - Economically Important Plant-Virus Vectors. G. Alberti and E. W. Kitajima, eds. Zoologica 160: 1-192. 
Kitajima, E. W., Chagas, C. M., and Rodrigues, J. C. V. 2003. Brevipalpus transmitted plant virus and virus-like diseases: Cytopathology and some recent cases. Exp. Appl. Acarol. 30:135-160.

Kitajima, E. W., Kondo, H., MacKenzie, A., Rezende, J. A. M., Gioria, R., Gibbs, A., and Tamada, T. 2001. Comparative cytopathology and immunocytochemistry of Japanese, Australian and Brazilian isolates of orchid fleck virus. J. Gen. Plant Pathol. 67:231-237.

Kitajima, E. W., Novelli, V. M., and Alberti, G. 2014. Anatomy and fine structure of Brevipalpus mites (Tenuipalpidae) - economically important plant-virus vectors - Part 1: An update on the biology and economic importance of Brevipalpus mites. Pages 1 to 10 in: Anatomy and Fine Structure of Brevipalpus Mites (Tenuipalpidae) - Economically Important Plant-Virus Vectors. G. Alberti and E. W. Kitajima, eds. Zoologica 160: 1-192.

Knorr, L. C. 1968. Studies on the etiology of leprosis in citrus. Proc. Conf. Int. Org. Citrus Virology, University of Florida Press 4:332-341.

Kubo, K. S., Novelli, V. M., Bastianel, M., Locali-Fabris, E. C., Antonioli-Luizon, R., Machado, M. A., and Freitas-Astu'a, J. 2011. Detection of Brevipalpus-transmitted viruses in their mite vectors by RT-PCR. Exp. Appl. Acarol. 54:33-39.

Kuchibhatla, D. B., Sherman, W. A., Chung, B. Y. W., Cook, S., Schneider, G., Eisenhaber, B., and Karline, D. G. 2014. Powerful sequence similarity search methods and in-depth manual analyses can identify remote homologs in many apparently "orphan". Viral Proteins J. Virol. 88:10-20.

León, G., Kitajima, E. W., Freitas, A., Machado, M., and Meza, N. 2006a. Detección del virus de la leprosis de los cítricos tipo citoplasmático en los Llanos Orientales de Colombia. Rev. Corpoica 7:67-72.

Leon, G. A., Becerra, C. H., Freitas-Astúa, J., Salaroli, R. B., and Kitajima, E. W. 2008. Natural infection of Swinglea glutinosa by the Citrus leprosis virus, cytoplasmic type (CiLV-C) in Colombia. Plant Dis. 92:1364.

León, G. A., Realpe, C. E., Garzon, P. A., Rodriguez, J. A., Moreno, M. G., Childers, C. C., Achor, D., Freitas-Astúa, J., Antonioli-Luizon, R., Salaroli, S. B., Cobo, N. C. M., and Kitajima, E. W. 2006b. Occurrence of Citrus leprosis virus in Llanos Orientales, Colombia. Plant Dis. 90:682.

Locali, E. C., Freitas-Astua, J., de Souza, A. A., Takita, M. A., Astua-Monge, G., Antonioli, R., Kitajima, E. W., and Machado, M. A. 2003. development of a molecular tool for the diagnosis of leprosis, a major threat to citrus production in the Americas. Plant Dis. 87:1317-1321.

Locali-Fabris, E. C., Freitas-Astua, J., Souza, A. A., Takita, M. A., Astua-Monge, G., Antonioli-Luizon, R., Rodrigues, V., Targon, M. L., and Machado, M. A. 2006. Complete nucleotide sequence, genomic organization and phylogenetic analysis of Citrus leprosis virus cytoplasmic type. J. Gen. Virol. 87:2721-2729.

Maeda, T., Kondo, H., Mitsuhata, K., and Tamada, T. 1998. Evidence that orchid fleck virus is efficiently transmitted in a persistent manner by the mite Brevipalpus californicus. Volume 3. 7th International Congress of Plant Pathology, Edinburgh, Scotland.

Melzer, M. J., Sether, D. M., Borth, W. B., and Hu, J. S. 2012. Characterization of a virus infecting Citrus volkameriana with citrus leprosis-like symptoms. Phytopathology 102:122-127.

Melzer, M. J., Simbajon, N., Carillo, J., Borth, W. B., Freitas-Astua, J., Kitajima, E. W., Neupane, K. R., and Hu, J. S. 2013. A cilevirus infects ornamental hibiscus in Hawaii. Arch. Virol. 158:2421-2424.

Mesa, N. C., Ochoa, R., Welbourn, W. C., Evans, G. A., and Moraes, G. J. 2008. A catalogue of Tenuipalpidae Berlese (Acari: Prostigmata) of the world, with a key to genera. Zootaxa 2098:1-185.

Miranda, L. C., Návia, D., and Rodrigues, J. C. V. 2007. Brevipalpus mites Donnadieu (Prostigmata: Tenuipalpidae) associated with ornamental plants in Distrito Federal, Brazil. Neotrop. Entomol. 36:587-592.

Muller, G. W., Targon, M. L. P. N., Carvalho, A. S., Souza, A. A., and Rodrigues, J. V. C. 2005. Doenças de citros causadas por virus e viróides. Pages 569-604 in: Citros. D. de Mattos Jr., J. D. de Negri, R. M. Pio, and J. Pompeu Jr., eds. Instituto Agronômico e Fundag, Campinas, Brazil.

Musumecci, M. R., and Rossetti, V. 1963. Transmissao de sintomas de leprose dos citros pelo ácaro Brevipalpus phoenicis. Cienc. Cult. 15:228.

Nabeshima, T., Inoue, S., Okamoto, K., Posadas-Herrera, G., Yu, F., Uchida, L., Ichinose, A., Sakaguchi, M., Sunahara, T., and Buerano, C. C. 2014. Tanay virus, a new species of virus isolated from mosquitoes in the Philippines. J. Gen. Virol. 95:1390-1395.

Navia, N., Mendonça, R. S., Ferragut, F., Miranda, L. C., Trincado, R. C., Michaux, J., and Navajas, M. 2013. Cryptic diversity in Brevipalpus mites (Tenuipalpidae). Zool. Scr. 42:406-426.

Nunes, M. A., Bergamini, M. P., Coerini, L. F., Bastianel, M., Novelli, V. M., Kitajima, E. W., and Freitas-Astúa, J. 2012a. Citrus leprosis virus $C$ naturally infecting Commelina benghalensis, a prevalent monocot weed of citrus orchards in Brazil. Plant Dis. 96:770.

Nunes, M. A., Oliveira, C. A. L., Oliveira, M. L., Kitajima, E. W., Hilf, M. E., Gottwald, R. T., and Freitas-Astúa, J. 2012b. Transmission of Citrus leprosis virus, cytoplasmic type, by Brevipalpus phoenicis (Geijskes) to alternate host plants found in citrus orchards. Plant Dis. 96: 968-972.

Pascon, R. C., Kitajima, J. P., Breton, M. C., Assumpcao, L., Greggio, C., Zanca, A. S., Okura, V. K., Alegria, M. C., Camargo, M. E., Silva, G. G., Cardozo, J. C., Vallim, M. A., Franco, S. F., Silva, V. H., Jordao, H., Jr., Oliveira, F., Giachetto, P. F., Ferrari, F., Aguilar-Vildoso, C. I., Franchiscini, F. J., Silva, J. M., Arruda, P., Ferro, J. A., Reinach, F., and da Silva, A. C. 2006. The complete nucleotide sequence and genomic organization of citrus leprosis associated virus, cytoplasmatic type (CiLV-C). Virus Genes 32: 289-298.

Pritchard, A. E., and Baker, E. W. 1952. The false spider mites of California (Acarina: Phytoptipalpidae). Univ. Calif. Publ. Entomol. 9:1-94.

Ramalho, T. O., Figueira, A. R., Sotero, A. J., Wang, R., Geraldino Duarte, P. S., Farman, M., and Goodin, M. M. 2014. Characterization of Coffee ringspot virus-Lavras: A model for an emerging threat to coffee production and quality. Virology 464-465C:385-396.

Rodrigues, J. C., Gall-Meagher, M., Ochoa, R., Childers, C. C., and Adams, B. J. 2004. Mitochondrial DNA and RAPD polymorphisms in the haploid mite Brevipalpus phoenicis (Acari: Tenuipalpidae). Exp. Appl. Acarol. 34: 275-290.

Rodrigues, J. C. V., Antony, L. M. K., Salaroli, R. B., and Kitajima, E. W. 2008. Brevipalpus-associated viruses in the central Amazon Basin. Trop. Plant Pathol. 33:12-19.

Rodrigues, J. C. V., and Childers, C. C. 2013. Brevipalpus mites (Acari: Tenuipalpidae): Vectors of invasive, non-systemic cytoplasmic and nuclear viruses in plants. Exp. Appl. Acarol. 59:165-175.

Rodrigues, J. C. V., Kitajima, E. W., Childers, C. C., and Chagas, C. M. 2003. Citrus leprosis virus vectored by Brevipalpus phoenicis (Acari: Tenuipalpidae) on citrus in Brazil. Exp. Appl. Acarol. 30:161-179.

Rodrigues, J. C. V., Locali, E. C., Freitas-Astúa, J., and Kitajima, E. W. 2005. Transmissibility of citrus leprosis virus by Brevipalpus phoenicis in Solanum violaefolium. Plant Dis. 89:911.

Rodrigues, J. C. V., Nogueira, N. L., Freitas, D. S., and Prates, H. S. 1997. Virus-like particles associated with Brevipalpus phoenicis Geijskes (Acari: Tenuipalpidae), vector of citrus leprosis virus. Ann. Soc. Entomol. Brasil 26:391-395.

Roy, A., Choudhary, N., Guillermo, L. M., Shao, J., Govindarajulu, A., Achor, D., Wei, G., Picton, D. D., Levy, L., Nakhla, M. K., Hartung, J. S., and Brlansky, R. H. 2013a. A novel virus of the genus Cilevirus causing symptoms similar to citrus leprosis. Phytopathology 103:488-500.

Roy, A., León, M. G., Stone, A. L., Schneider, W. L., Hartung, J. S., and Brlansky, R. H. 2014. First report of Citrus leprosis virus nuclear type in sweet orange in Colombia. Plant Dis. 98:1162.

Roy, A., Stone, A., Otero-Colina, G., Wei, G., Choudhary, N., Achor, D., Shao, J., Levy, L., Nakhla, M. K., Hollingsworth, C. R., Hartung, J. S., Schneider, W. L., and Brlansky, R. H. 2013b. Genome assembly of Citrus leprosis virus nuclear type reveals a close association with orchid fleck virus. Genome Announc. 1(4):e00519-13.

Roy, A., Stone, A. L., Shao, J., Otero-Colina, G., Wei, G., Achor, D., Choudhary, N., Levy, L., Nakhla, M. K., Hartung, J. S., Schneider, W. L., and Brlansky, R. H. 2015. Identification and molecular characterization of nuclear Citrus leprosis virus, a member of the proposed Dichorhavirus genus infecting multiple Citrus species in Mexico. Phytopathology 105: 564-575.

Salinas-Vargas, D., Santillán-Galicia, M. T., Valdez-Carrasco, J., Mora-Aguilera, G., Atanacio-Serrano, Y., and Romero-Pescador, P. 2013. Species composition and abundance of Brevipalpus spp. in different Citrus species in Mexican orchards. Neotrop. Entomol. 42:419-425.

Salva, R. A., and Massari, C. A. 1995. Situação do ácaro da leprose no estado de São Paulo, levantamento - Fundecitrus, agosto 1995. Pages 13-17 in: Leprose dos citros. C. A. L. Oliveira and L. C. Donadio, eds. Funep. Jaboticabal, Brazil.

Tamura, K., Stecher, G., Peterson, D., Filipski, A., and Kumar, S. 2013. MEGA6: Molecular evolutionary genetics analysis version 6.0. Mol. Biol. Evol. 30:2725-2729.

Welbourn, W. C., Ochoa, R., Kane, E. C., and Erbe, E. F. 2003. Morphological observations on Brevipalpus phoenicis (Acari: Tenuipalpidae) including comparisons with B. californicus and B. obovatus. Exp. Appl. Acarol. 30: $107-133$ 